\title{
Thermal stability of the crystal structure and electronic properties of the high power factor thermoelectric colusite $\mathrm{Cu}_{26} \mathrm{Cr}_{2} \mathrm{Ge}_{6} \mathrm{~S}_{32}$
}

\author{
Pierric Lemoine, ${ }^{\mathrm{a},{ }^{*}}$ Ventrapati Pavan Kumar, ${ }^{\mathrm{b}}$ Gabin Guélou, ${ }^{\mathrm{b}}$ Vivian Nassif,c,d Bernard Raveau, ${ }^{\mathrm{b}}$
} Emmanuel Guilmeau ${ }^{\mathrm{b}}$

a Univ Rennes, CNRS, Institut des Sciences Chimiques de Rennes - UMR 6226, F-35000 Rennes, France

b CRISMAT, CNRS, Normandie Univ, ENSICAEN, UNICAEN, 14000 Caen, France

${ }^{c}$ CNRS Institut Néel, F-38000 Grenoble, France

d Université de Grenoble Alpes, Institut Néel, F-38000 Grenoble, France

* pierric.lemoine@univ-rennes1.fr

\begin{abstract}
A complete study on the thermal stability of the crystal structure and electrical properties, as well as on the phase decomposition, of the high performance thermoelectric colusite $\mathrm{Cu}_{26} \mathrm{Cr}_{2} \mathrm{Ge}_{6} \mathrm{~S}_{32}$ is presented. Combination of results from differential scanning calorimetry, thermogravimetric analysis, in situ neutron powder diffraction, and Seebeck coefficient and electrical resistivity temperature cycling experiments show that the high thermoelectric performance colusite $\mathrm{Cu}_{26} \mathrm{Cr}_{2} \mathrm{Ge}_{6} \mathrm{~S}_{32}$ is stable at least up to $700 \mathrm{~K}$ in a non-oxidative atmosphere. A superficial sulfur loss without phase decomposition is observed above $\approx 760 \mathrm{~K}$, leading to a progressive increase of both electrical resistivity and Seebeck coefficient. The colusite phase, $\mathrm{Cu}_{26} \mathrm{Cr}_{2} \mathrm{Ge}_{6} \mathrm{~S}_{32}$, starts to decompose above $830 \mathrm{~K}$ into $\mathrm{Cu}_{8} \mathrm{GeS}_{6}$ and $\mathrm{CuCrS}_{2}$ phases. This leads to a $\mathrm{Ge}$ enrichment of the colusite phase (i.e. decrease of the $\mathrm{Cu} / \mathrm{Ge}$ ratio). This initial decomposition step is followed by a second one above $880 \mathrm{~K}$, related to the structural modification from the cubic structure of colusite into the monoclinic $\mathrm{Cu}_{2} \mathrm{GeS}_{3}$ structure. Above $930 \mathrm{~K}$, the colusite $\mathrm{Cu}_{26} \mathrm{Cr}_{2} \mathrm{Ge}_{6} \mathrm{~S}_{32}$ phase is fully decomposed. The influence on the crystal structure of the superficial sulfur loss detected a few dozens of degrees before the colusite $\mathrm{Cu}_{26} \mathrm{Cr}_{2} \mathrm{Ge}_{6} \mathrm{~S}_{32} \mathrm{phase}$ decomposition is discussed and compared to the results obtained on the colusite $\mathrm{Cu}_{26} \mathrm{~V}_{2} \mathrm{Ge}_{6} \mathrm{~S}_{32}$ phase, stable at least up to $1000 \mathrm{~K}$. A singular thermal evolution of the unit cell parameter of the latter is observed and discussed. Finally, a discussion on the thermoelectric performance optimization by process-induced structural disordering in these two colusite phases is given.
\end{abstract}

\section{INTRODUCTION}

In the current global warming crisis, development of alternative technologies to fossil energy such as thermoelectricity, i.e. the conversion of waste heat into electricity, is mandatory. Improvement of the conversion efficiency in line with environmental and cost constraints require the development of new performant thermoelectric materials made of non-toxic and cheap elements. In this context, ternary and quaternary copper-based sulfides, derived from mineral phases, have attracted more and more attention over the past few years: bornite $\mathrm{Cu}_{5-x} T_{x} \mathrm{Fe}_{1-y} M_{y} \mathrm{~S}_{4}(T=\mathrm{Co}, \mathrm{Zn} ; M=\mathrm{Mn}$, $\mathrm{Zn} ; x \leq 0.1 ; y \leq 0.1),{ }^{1-7}$ isocubanite $\mathrm{Cu}_{2} \mathrm{FeS}_{3},{ }^{8}$ famatinite $\mathrm{Cu}_{3} \mathrm{Sb}_{1-}$ ${ }_{x} M_{x} \mathrm{~S}_{4}(M=\mathrm{Ge}, \mathrm{Sn} ; x \leq 0.15),{ }^{9,10}$ mohite $\mathrm{Cu}_{2} \mathrm{Sn}_{1-x} M_{x} \mathrm{~S}_{3}(M=\mathrm{Co}$, $\mathrm{Zn}, \mathrm{In} ; x \leq 0.25),{ }^{11-13}$ stannite/kuramite $\mathrm{Cu}_{2+x} \mathrm{Fe}_{1-x} \mathrm{SnS}_{4}(0 \leq x \leq$ 1), ${ }^{14,15}$ kesterite $\mathrm{Cu}_{2} \mathrm{ZnSnS}_{4},{ }^{16}$ mawsonite $\mathrm{Cu}_{6} \mathrm{Fe}_{2} \mathrm{SnS}_{8}{ }^{17}$ stannoidite $\mathrm{Cu}_{8+x} \mathrm{Fe}_{3-x} \mathrm{Sn}_{2} \mathrm{~S}_{12}(x \leq 0.5),{ }^{18}$ tetrahedrite $\mathrm{Cu}_{12}$ ${ }_{x} T_{x} \mathrm{Sb}_{4} \mathrm{~S}_{13}(T=\mathrm{Mn}, \mathrm{Fe}, \mathrm{Co}, \mathrm{Ni}, \mathrm{Zn}, \mathrm{Mg} ; x \leq 2),{ }^{19-27}$ germanite $\mathrm{Cu}_{26-x} \mathrm{Fe}_{4+x} \mathrm{Ge}_{4} \mathrm{~S}_{32}(3.6 \leq x \leq 4.0){ }^{28}$ renierite $\mathrm{Cu}_{22-x} \mathrm{Zn}_{x} \mathrm{Fe}_{8} \mathrm{Ge}_{4} \mathrm{~S}_{32}$ $(1.2 \leq x \leq 2.0),{ }^{29}$ and colusite $\mathrm{Cu}_{26} T_{2} M_{6} \mathrm{~S}_{32}(T=\mathrm{V}, \mathrm{Nb}, \mathrm{Ta}, \mathrm{Cr}$, Mo, W; $M=\mathrm{Ge}, \mathrm{Sn}) .{ }^{30-41}$ Among these materials, the synthetic colusite $\mathrm{Cu}_{26} \mathrm{Cr}_{2} \mathrm{Ge}_{6} \mathrm{~S}_{32}$ appears to be one of the most promising $p$-type representatives with its high power factor $P F\left(=S^{2} / \rho\right.$, where $S$ is the Seebeck coefficient and $\rho$ is the electrical resistivity) close to $1.5 \mathrm{~mW} \mathrm{~m}^{-1} \mathrm{~K}^{-2}$ at $300 \mathrm{~K}$ and $2.0 \mathrm{~mW} \mathrm{~m}^{-1}$ $\mathrm{K}^{-2}$ at $700 \mathrm{~K}^{39}$ Moreover, these unprecedented electrical properties among copper-based sulfides are combined with a relatively low thermal conductivity $\kappa$, close to $3.0 \mathrm{~W} \mathrm{~m}^{-1} \mathrm{~K}^{-1}$ at $300 \mathrm{~K}$ and $1.6 \mathrm{~W} \mathrm{~m}^{-1} \mathrm{~K}^{-1}$ at $700 \mathrm{~K}$. This allows this material to reach a figure of merit $Z T\left(=S^{2} T / \rho \kappa, T\right.$ being the absolute temperature) close to unity at $700 \mathrm{~K}$ and more importantly one of the best average $Z T$ values (close to 0.5 over the $300-700 \mathrm{~K}$ temperature range) among this family of materials. ${ }^{39}$ As described in our previous works, ${ }^{39,41}$ the outstanding electronic transport properties of the synthetic colusite $\mathrm{Cu}_{26} \mathrm{Cr}_{2} \mathrm{Ge}_{6} \mathrm{~S}_{32}$ are related to singular interactions between mixed tetrahedraloctahedral complexes $\left[\mathrm{CrS}_{4}\right] \mathrm{Cu}_{6}$ (arising from the metal-metal interactions between the interstitial $\mathrm{Cr}$ atom and the $\mathrm{Cu}$ atoms of the host sphalerite framework) and the iono-covalent conductive "Cu-S" network (i.e. sphalerite framework " $\mathrm{Cu}_{26} \mathrm{Ge}_{6} \mathrm{~S}_{32}$ " by omitting Ge atoms). These results revealed that the thermoelectric properties of the synthetic colusite $\mathrm{Cu}_{26} \mathrm{Cr}_{2} \mathrm{Ge}_{6} \mathrm{~S}_{32}$ are mostly limited by its thermal conductivity. One possible way to reduce the thermal lattice conductivity is to generate phonon scattering from structural disorder, as demonstrated in synthetic colusite $\mathrm{Cu}_{26} \mathrm{~V}_{2} \mathrm{Sn}_{6} \mathrm{~S}_{32} \cdot{ }^{36}$ Indeed, a severe reduction of the lattice thermal conductivity of this material (from $1.4 \mathrm{~W} \mathrm{~m}^{-1} \mathrm{~K}^{-1}$ down to $0.4 \mathrm{~W} \mathrm{~m}^{-1} \mathrm{~K}^{-1}$ at $300 \mathrm{~K}$ and from $0.6 \mathrm{~W} \mathrm{~m}^{-1} \mathrm{~K}^{-1}$ down to $0.3 \mathrm{~W} \mathrm{~m}^{-1} \mathrm{~K}^{-1}$ at $675 \mathrm{~K}$ ) without affecting its power factor significantly was achieved by controlling the densification process at high temperature and 
structural disorder. This leads to an improvement by about $300 \%$ of the figure of merit on the full temperature range. ${ }^{36}$ The reason behind the present thermal stability study is twofold. First, the temperature limit for future potential applications can be determined. Secondly, the feasibility of the temperatureinduced disorder approach, successful in colusite $\mathrm{Cu}_{26} \mathrm{~V}_{2} \mathrm{Sn}_{6} \mathrm{~S}_{32}$, can be investigated in order to improve the thermoelectric performance of colusite $\mathrm{Cu}_{26} \mathrm{Cr}_{2} \mathrm{Ge}_{6} \mathrm{~S}_{32}$.

Moreover, while some inorganic sulfide compounds are reported with either $\mathrm{Mo}^{6+42-45}$ or $\mathrm{W}^{6+46-52}$ cations in a tetrahedral environment of sulfur, the synthetic colusite $\mathrm{Cu}_{26} \mathrm{Cr}_{2} \mathrm{Ge}_{6} \mathrm{~S}_{32}$ is, to the best of our knowledge, the unique representative involving $\mathrm{Cr}^{6+}$ cations in such kind of chemical environment. This was assumed to be related to the smaller ionic size and lower electronegativity of $\mathrm{Cr}^{6+}$ cation $^{39}$ that should lead to lower thermal stability of $\mathrm{Cr}^{6+}$ containing sulfides compared to those involving $\mathrm{Mo}^{6+}, \mathrm{W}^{6+}$ or $\mathrm{V}^{5+}$ cations. Thus, in addition to the aforementioned applicative interests, the determination of the thermal stability of the colusite $\mathrm{Cu}_{26} \mathrm{Cr}_{2} \mathrm{Ge}_{6} \mathrm{~S}_{32}$ presents also an interest from the crystal chemistry point of view.

\section{EXPERIMENTAL SECTION}

Synthesis. Polycrystalline samples of colusite $\mathrm{Cu}_{26} \mathrm{Cr}_{2} \mathrm{Ge}_{6} \mathrm{~S}_{32}$ were synthesized by mechanical alloying and spark plasma sintering following the procedure described elsewhere. ${ }^{39}$ The resulting pellets were either cut in rectangular ingots to perform temperature cycling measurements of the electrical and thermal properties or ground in agate mortar and sieved down to $150 \mu \mathrm{m}$ to perform diffraction and DSC/TG analyses.

Differential scanning calorimetry and thermogravimetric analysis. Phase transitions and weight loss were investigated by Differential Scanning Calorimetry (DSC) and ThermoGravimetric Analysis (TGA) respectively, both using a Netzsch STA 449 F3 Jupiter apparatus equipped with a TASC414/4 controller. DSC/TG measurements were carried out on a powdered sample simultaneously from room temperature up to $973 \mathrm{~K}$ at the rate of 2 $\mathrm{K} \mathrm{min}{ }^{-1}$ under argon flow in order to avoid oxidation of the sample. The experimental data were not corrected for the instrumental contributions.

X-ray and neutron powder diffraction. The purity of the samples and the crystal structure of the phases, before and after high temperature characterizations, were checked at room temperature and in air by X-ray powder diffraction (XRPD). Highresolution data were collected using a Bruker D8 Advance Vario 1 two-circle diffractometer ( $\theta-2 \theta$ Bragg-Brentano mode) equipped with a $\mathrm{Cu} \mathrm{K} \alpha \mathrm{X}$-ray tube, a $\mathrm{Ge}$ (111) monochromator (Johansson type) and a LynxEye detector. The structural and chemical stability of the title compound was studied by in situ neutron powder diffraction (NPD) at high temperature at the Institut Laue Langevin (ILL), Grenoble, France. The neutron data were collected from room temperature up to $973 \mathrm{~K}$ under dynamical secondary vacuum using the high flux neutron two-axis powder diffractometer D1B $(\lambda$ $=1.28 \AA$ ) equipped with a one-dimensional curved multidetector. The analysis of the diffraction patterns was performed by Rietveld profile refinement using the FullProf and WinPlotr software packages. ${ }^{53,54}$ NPD refinements were conducted by considering a polynomial function of order 10 for the background description.

Thermoelectric properties measurements. The electrical resistivity $(\rho)$ and Seebeck coefficient $(S)$ were measured simultaneously from ingots using an ULVAC-ZEM3 instrument under partial helium pressure. The samples were cut in the form of parallelepipeds with dimensions of around $3 \times 3 \times 10 \mathrm{~mm}^{3}$. A first measurement including 7 cycles of heating and cooling $(300 \mathrm{~K}$ $700 \mathrm{~K}-300 \mathrm{~K}$ ) was performed, followed by a second measurement including 7 cycles of heating and cooling $(300 \mathrm{~K}-760 \mathrm{~K}-300 \mathrm{~K})$. Heating and cooling rates were approximately of $2 \mathrm{~K} \mathrm{~min}^{-1}$.

\section{RESULTS AND DISCUSSION}

Sample purity and crystal structure description of colusite. XRPD data acquired on the colusite $\mathrm{Cu}_{26} \mathrm{Cr}_{2} \mathrm{Ge}_{6} \mathrm{~S}_{32}$ sample after the two-step synthesis process (i.e. mechanical alloying and spark plasma sintering) exhibit the diffraction peaks of the colusite structure only, confirming the absence of secondary phase. Colusite $\mathrm{Cu}_{26} \mathrm{Cr}_{2} \mathrm{Ge}_{6} \mathrm{~S}_{32}$ crystallizes in the non-centrosymmetric space group of cubic symmetry $P \overline{4} 3 n$ with a room temperature unit cell parameter $a=10.5524(1) \AA$. It can be viewed as a superstructure of the cubic sphalerite $\mathrm{ZnS}$ structure $\left(F \overline{4} 3 m, \mathrm{a}_{\mathrm{s}} \approx 5.4 \AA\right)$ with a $2 \mathrm{a}_{\mathrm{s}} \times 2 \mathrm{a}_{\mathrm{s}} \times 2 \mathrm{a}_{\mathrm{s}}$ supercell induced by an ordered distribution of the metallic cations related to the sphalerite framework " $\mathrm{Cu}_{26} \mathrm{Ge}_{6} \mathrm{~S}_{32}$ " on four different crystallographic sites (i.e. $6 c, 6 d, 8 e$ and $12 f$ ) and the occupation of the "interstitial" $2 a$ site (referring to the $P \overline{4} 3 n$ space group) by $\mathrm{Cr}^{6+}$ cations. ${ }^{39}$ Each cation is in a tetrahedral environment of sulfur anions, the latter being located on two different crystallographic sites (i.e. $8 e$ and $24 i$ ). The sphalerite framework " $\mathrm{Cu}_{26} \mathrm{Ge}_{6} \mathrm{~S}_{32}$ ", built up of corner-sharing $\mathrm{GeS}_{4}$ and $\mathrm{CuS}_{4}$ tetrahedra, hosts the "interstitial" $\mathrm{Cr}^{6+}$ cations at the center of a tetrahedron of sulfur sharing edges with the six surrounding $\mathrm{CuS}_{4}$ tetrahedra $(\mathrm{Cu}$ in $12 f$ site). This structural feature, also observed in sulvanite structure and derivative sulfides, ${ }^{39,55}$ leads to abnormally short distances of $2.709 \AA$ between $\mathrm{Cr}$ and its six $\mathrm{Cu}$ nearest neighbors considered as cations. This implies strong $\mathrm{Cr}-\mathrm{Cu}$ interactions, which compete with iono-covalent $\mathrm{Cr}-\mathrm{S}$ bonds, and consequently to the existence of mixed tetrahedraloctahedral complexes $\left[\mathrm{CrS}_{4}\right] \mathrm{Cu}_{6}$ isolated from one another. ${ }^{39} \mathrm{It}$ is worth noting that the interactions between these complexes and the conductive " $\mathrm{Cu}-\mathrm{S}$ " network are responsible for the outstanding electrical transport properties of this colusite. ${ }^{39,41}$

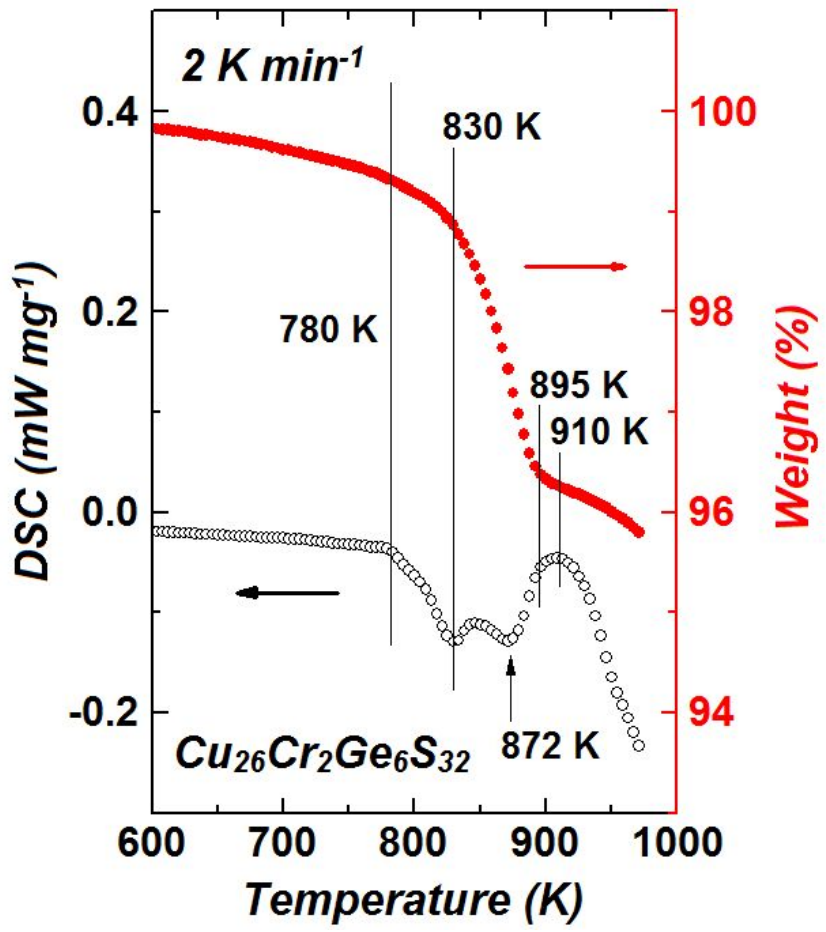

Figure 1. Differential scanning calorimetry and thermogravimetric data for colusite $\mathrm{Cu}_{26} \mathrm{Cr}_{2} \mathrm{Ge}_{6} \mathrm{~S}_{32}$ from $600 \mathrm{~K}$ up to $973 \mathrm{~K}$ at the heating rate of $2 \mathrm{~K} \mathrm{~min}^{-1}$. 
DSC/TGA measurements. Phase transitions and weight loss determined by DSC/TGA measurements from room temperature up to $973 \mathrm{~K}$ at the heating rate of $2 \mathrm{~K} \mathrm{~min}^{-1}$ are shown in Figure 1. Neither signal on the DSC curve nor significant weight loss are detected up to $780 \mathrm{~K}$, indicating that the colusite $\mathrm{Cu}_{26} \mathrm{Cr}_{2} \mathrm{Ge}_{6} \mathrm{~S}_{32}$ compound is stable up to $780 \mathrm{~K}$ in a non-oxidative atmosphere. At higher temperature, both endothermic peaks and weight loss are detected. Thermogravimetric analysis reveals a significant weight loss of about $3 \%$ from $830 \mathrm{~K}$ to $895 \mathrm{~K}$, attributed to sulfur volatilization. The DSC curve exhibits a weak endothermic signal starting at $780 \mathrm{~K}$ followed by two endothermic peaks with a maximum at $830 \mathrm{~K}$ and $872 \mathrm{~K}$ respectively and a broad endothermic signal above $910 \mathrm{~K}$. The temperatures for which the sample begins and finishes to loose mass significantly coincide with the maximum of the first endothermic peak (i.e. $830 \mathrm{~K}$ ) and the end of the second endothermic peak (i.e. $895 \mathrm{~K}$ ), respectively (Figure 1). However, weight loss continues progressively at higher temperature and reaches a value close to $4 \%$ at around $950 \mathrm{~K}$, corresponding to $\approx 4$ atoms of sulfur per formula unit.

High temperature in situ neutron powder diffraction measurements. In order to study the structural and chemical stability of the colusite $\mathrm{Cu}_{26} \mathrm{Cr}_{2} \mathrm{Ge}_{6} \mathrm{~S}_{32}$ compound, in situ NPD patterns were recorded every $10 \mathrm{~K}$ from $573 \mathrm{~K}$ up to $973 \mathrm{~K}$ (heating rate of $2 \mathrm{~K} \mathrm{~min}^{-1}, 5$ minutes per pattern). The neutron wavelength $(\lambda=1.2847(1) \AA)$ was refined using long duration NPD pattern recorded at $293 \mathrm{~K}$ by fixing the unit cell parameter of $\mathrm{Cu}_{26} \mathrm{Cr}_{2} \mathrm{Ge}_{6} \mathrm{~S}_{32}$ to the value refined from room temperature XRPD data $(a=10.5524(1) \AA)$. The refined neutron wavelength was then used for the following neutron data refinements.
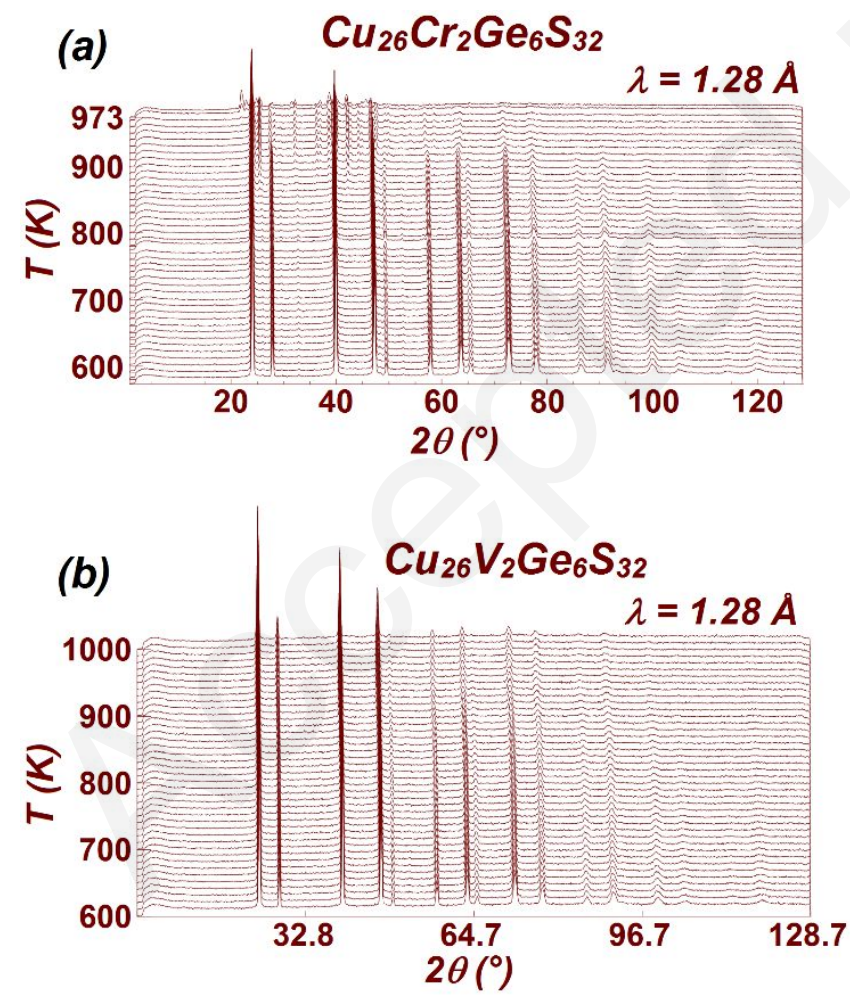

Figure 2. High temperature neutron thermograms of colusites $\mathrm{Cu}_{26} \mathrm{Cr}_{2} \mathrm{Ge}_{6} \mathrm{~S}_{32}$ (a) and $\mathrm{Cu}_{26} \mathrm{~V}_{2} \mathrm{Ge}_{6} \mathrm{~S}_{32}$ (b) recorded at the heating rate of $2 \mathrm{~K} \mathrm{~min}^{-1}$.
A qualitative analysis of the high temperature in situ NPD patterns suggests a structural stability of the colusite framework up to $\approx 850 \mathrm{~K}$ (Figure 2a). Above this temperature, the NPD patterns are characterized by the successive appearance of diffraction peaks arising from secondary phases concomitantly with the vanishing of colusite diffraction peaks. A careful analysis of the NPD patterns reveals that the superstructure diffraction peaks characteristic of the colusite structure are detected up to $880 \mathrm{~K}$, while their existence at higher temperature is not confirmed. Consequently, Rietveld refinements of the NPD data recorded up to $880 \mathrm{~K}$ were performed by considering a colusite structure. From these refinements an almost linear thermal evolution of the unit cell parameter of the colusite $\mathrm{Cu}_{26} \mathrm{Cr}_{2} \mathrm{Ge}_{6} \mathrm{~S}_{32}$ up to $830 / 840 \mathrm{~K}$ could be observed, followed by a relatively constant unit cell parameter and an increase of its standard deviation at higher temperature (Figure 3). This behavior modification is linked to the appearance of diffraction peaks arising from secondary phases at $840 \mathrm{~K}$ (Figure $4 \mathrm{a}$ ) and supported by the huge increase of the $\chi^{2}$ value above $850 \mathrm{~K}$ when only a colusite phase is considered in the refinement (inset of Figure 3). The high quality Rietveld refinement of the NPD pattern recorded at 830 $\mathrm{K}$, shown in Figure $5 \mathrm{a}$, confirms that the sample consists exclusively of the colusite $\mathrm{Cu}_{26} \mathrm{Cr}_{2} \mathrm{Ge}_{6} \mathrm{~S}_{32}$ phase at this temperature. Moreover, from Rietveld refinements of NPD data recorded up to $830 \mathrm{~K}$, it should be mentioned that (i) the fractional atomic coordinates of the colusite $\mathrm{Cu}_{26} \mathrm{Cr}_{2} \mathrm{Ge}_{6} \mathrm{~S}_{32}$ phase do not evolve with temperature and (ii) the isotropic displacement parameters of atoms of this phase increase linearly with temperature, with the exception of $\mathrm{Cr}$ atom which shows a constant $B_{\text {iso }}$ value probably related to its specific chemical environment. Note that similar in situ NPD diffraction measurements were performed on a colusite $\mathrm{Cu}_{26} \mathrm{~V}_{2} \mathrm{Ge}_{6} \mathrm{~S}_{32}$ sample. This high temperature characterization indicates the absence of phase decomposition for this colusite up to at least $1000 \mathrm{~K}$ (Figure 2b).

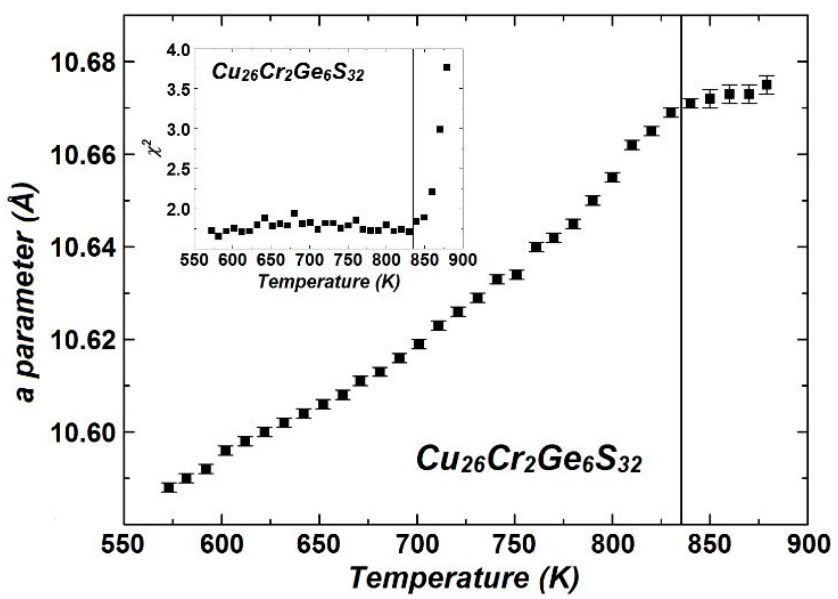

Figure 3. Thermal evolution of the colusite $\mathrm{Cu}_{26} \mathrm{Cr}_{2} \mathrm{Ge}_{6} \mathrm{~S}_{32}$ unit cell parameter determined from Rietveld refinements of the NPD data. The $\chi^{2}$ values of the refinements for which only colusite structure was considered are given as an inset. 
(a)

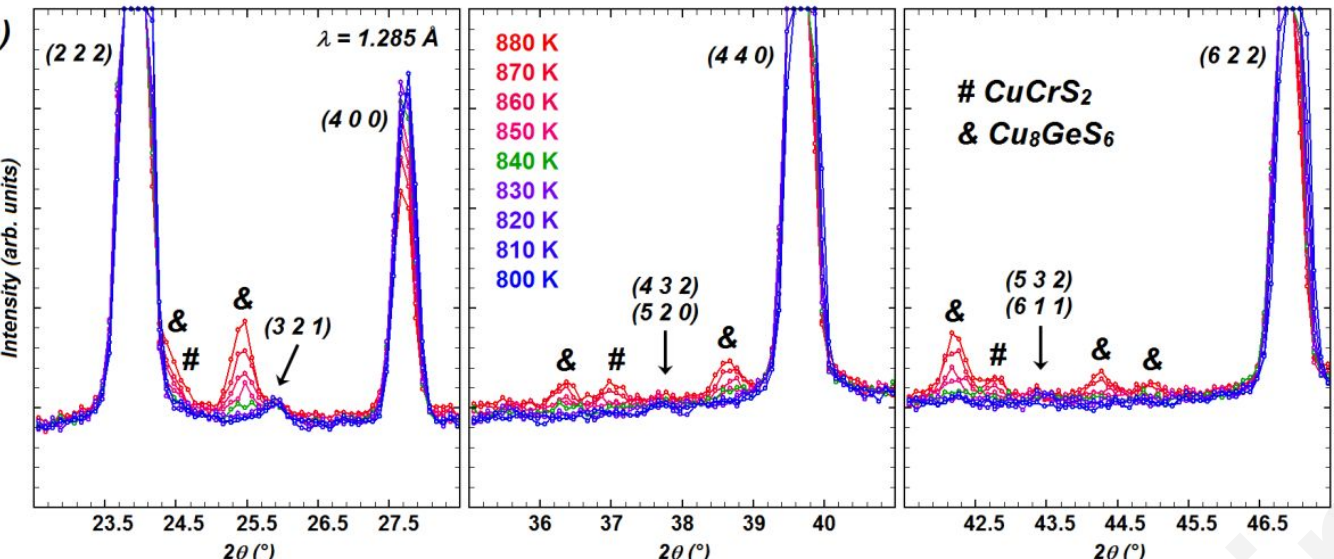

(b)

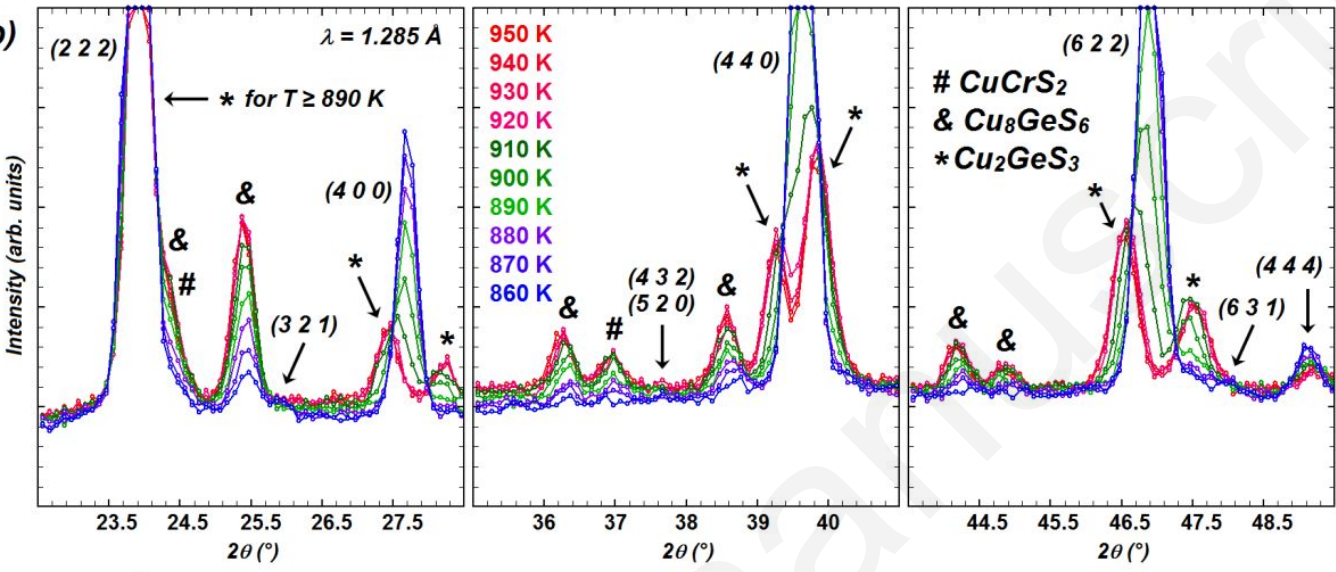

(c)

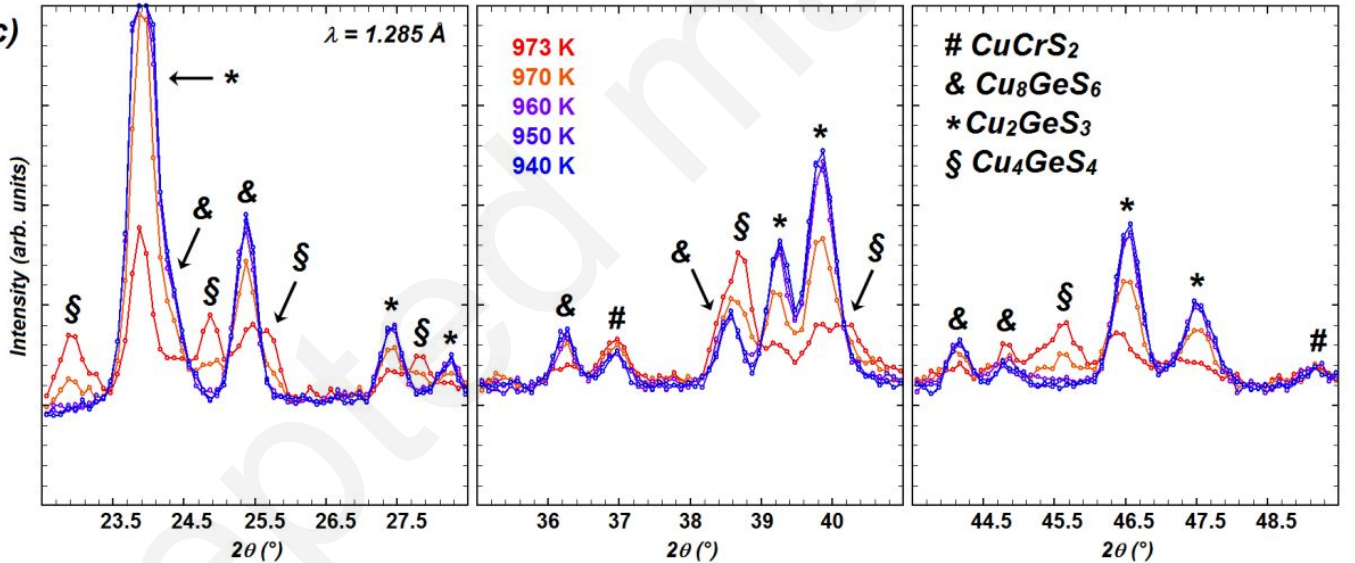

Figure 4. Thermal evolution of the NPD patterns of the colusite $\mathrm{Cu}_{26} \mathrm{Cr}_{2} \mathrm{Ge}_{6} \mathrm{~S}_{32}$ sample recorded between: (a) $800 \mathrm{~K}$ and $880 \mathrm{~K}$; (b) $860 \mathrm{~K}$ and $950 \mathrm{~K}$; (c) $940 \mathrm{~K}$ and $973 \mathrm{~K}$ (heating rate of $2 \mathrm{~K} \mathrm{~min}^{-1}$ ). Symbols \#, \&, *, and $\S$ refer to $\mathrm{CuCrS}_{2}$ phase in its high temperature form, $\mathrm{Cu}_{8} \mathrm{GeS}_{6}$ in its high temperature cubic form, $\mathrm{Cu}_{2} \mathrm{GeS}_{3}$ in its monoclinic form, and $\mathrm{Cu}_{4} \mathrm{GeS}_{4}$ in its monoclinic form, respectively.

As previously mentioned, the in situ NPD study reveals that the colusite $\mathrm{Cu}_{26} \mathrm{Cr}_{2} \mathrm{Ge}_{6} \mathrm{~S}_{32}$ phase starts to decompose above $\approx$ $830 \mathrm{~K}$ in a non-oxidative atmosphere (Figure 4a). Despite the relatively low intensity diffraction peaks of the phases arising from the thermal decomposition of the colusite $\mathrm{Cu}_{26} \mathrm{Cr}_{2} \mathrm{Ge}_{6} \mathrm{~S}_{32}$, it was possible to determine their crystal symmetry and to estimate their chemical composition. Indeed, diffraction peaks observed around $24.5^{\circ}, 37.0^{\circ}$ and $42.6^{\circ}$ (Figure $4 \mathrm{a}$ ) are related to the $\mathrm{CuCrS}_{2}$ phase, which crystallizes in the trigonal space group $R 3 m$ with unit cell parameters $a=3.509(2) \AA$ and $c=$ $18.828(19) \AA$ at $\mathrm{T}=880 \mathrm{~K}$ (Figure $5 \mathrm{~b}$ ). This high temperature form, reported to be stable above $673 \mathrm{~K},{ }^{56}$ was assumed to be correct and was used in the NPD data refinements. The remaining diffraction peaks originating from the thermal decomposition of colusite $\mathrm{Cu}_{26} \mathrm{Cr}_{2} \mathrm{Ge}_{6} \mathrm{~S}_{32}$ (i.e. around $24.5^{\circ}$, $25.5^{\circ}, 36.2^{\circ}, 38.3^{\circ}, 42.3^{\circ}, 44.4^{\circ}$, and $44.7^{\circ}$, Figure $\left.4 a\right)$ can be indexed with the cubic space group $F \overline{4} 3 \mathrm{~m}$ and cell parameter $a$ $\approx 10.05 \AA$. These results are in agreement with the formation of the high temperature cubic form of the $\mathrm{Cu}_{8} \mathrm{GeS}_{6}$ phase, a representative of the argyrodite-type chalcogenides family $\mathrm{A}^{\mathrm{m}+}{ }_{(12-\mathrm{n}) / \mathrm{m}} \mathrm{B}^{\mathrm{n}+} \mathrm{X}^{2-}{ }_{6}$, which exhibits a structural phase transition at $328 \mathrm{~K}$ from an orthorhombic symmetry to a cubic symmetry. ${ }^{.7}$ Consequently, the diffraction peaks arising from the cubic phase of space group $F \overline{4} 3 \mathrm{~m}$ have been attributed to the high temperature form of $\mathrm{Cu}_{8} \mathrm{GeS}_{6}$. Three structural models have been considered and tested for this phase: $\mathrm{Cu}_{8} \mathrm{GeS}_{6}$ in 
$\mathrm{Ag}_{8} \mathrm{GeTe}_{6}$-type ${ }^{58} \mathrm{Cu}_{9} \mathrm{GeS}_{5.42}$ in $\mathrm{Ag}_{9} \mathrm{GaSe}_{6}$-type, ${ }^{59}$ and $\mathrm{Cu}_{8} \mathrm{GeS}_{6}$ in $\mathrm{Ag}_{3.3} \mathrm{Cu}_{4.7} \mathrm{GeS}_{6}$-type ${ }^{60}$ for which $\mathrm{Ag}$ atoms have been replaced by $\mathrm{Cu}$ atoms. The best refinement was obtained with the latter which corresponds to a putzite mineral derivative structure (Figure 5b). Unfortunately, the exact structural model of the high temperature form of $\mathrm{Cu}_{8} \mathrm{GeS}_{6}$ cannot be determined from our NPD data.

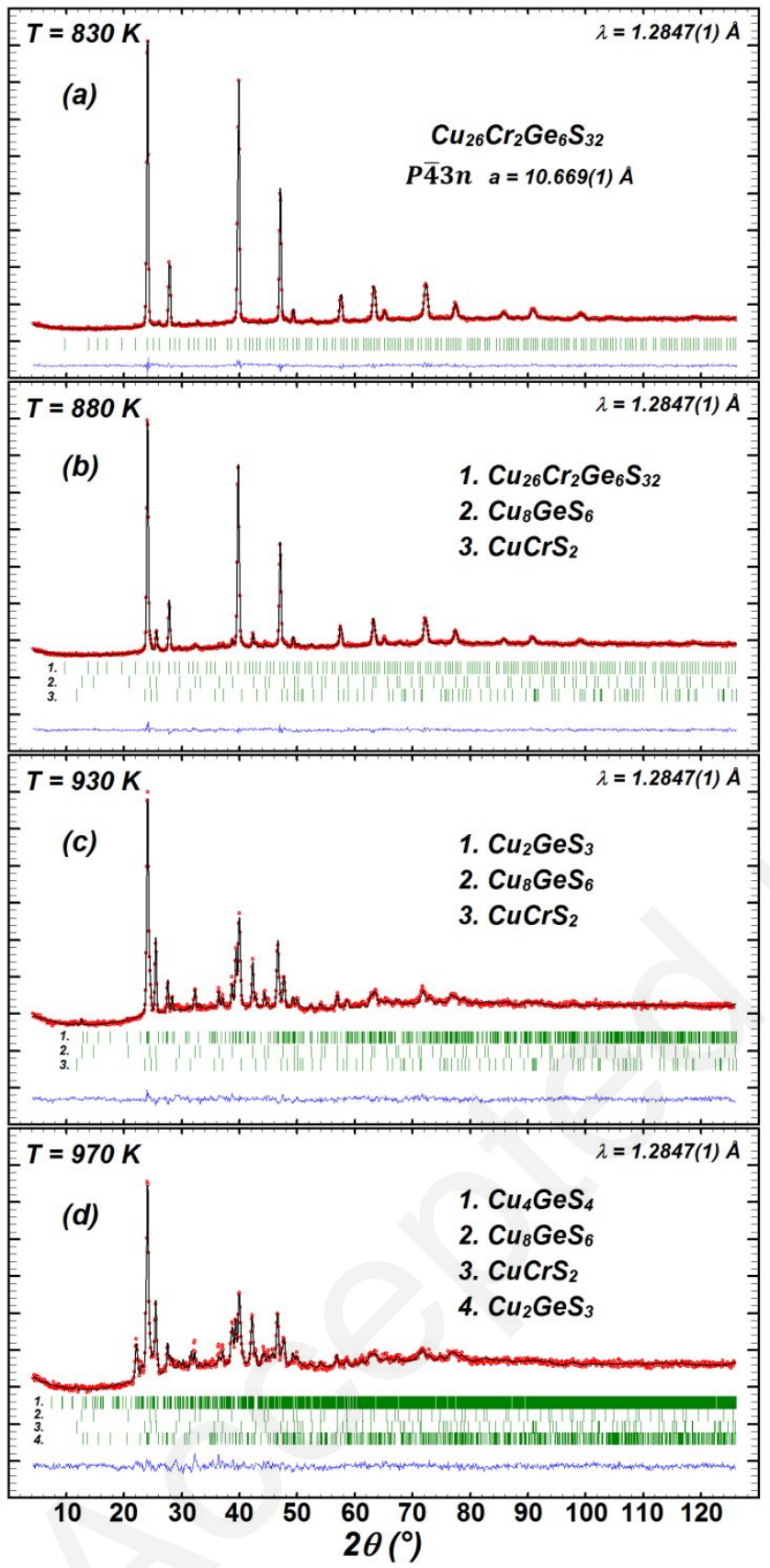

Figure 5. Rietveld refinements of the NPD patterns showing the nature of the phases resulting from the decomposition of the colusite $\mathrm{Cu}_{26} \mathrm{Cr}_{2} \mathrm{Ge}_{6} \mathrm{~S}_{32}$ at (a) $\mathrm{T}=830 \mathrm{~K}$, (b) $\mathrm{T}=880 \mathrm{~K}$, (c) $\mathrm{T}=930$ $\mathrm{K}$, and (d) $\mathrm{T}=970 \mathrm{~K}$ (heating rate of $2 \mathrm{~K} \mathrm{~min}^{-1}$ ).

Hence, this in situ NPD investigation suggests that the colusite $\mathrm{Cu}_{26} \mathrm{Cr}_{2} \mathrm{Ge}_{6} \mathrm{~S}_{32}$ phase is stable up to $\approx 830 \mathrm{~K}$ (Figure $5 \mathrm{a}$ ) and starts to decompose above this temperature into $\mathrm{Cu}_{8} \mathrm{GeS}_{6}$ and $\mathrm{CuCrS}_{2}$ phases, both in their high temperature forms. The formation of these two ternary copper sulfides containing germanium or chromium atoms, was confirmed by Rietveld refinement of the XRPD data recorded at room temperature on the sample after thermal treatment (Figure 6). Both phases were found to crystallize in their room temperature crystal structure: $\mathrm{CuCrS}_{2},{ }^{56}$ trigonal space group $R 3 \mathrm{~m}$ with refined unit cell parameters $a=3.480(1) \AA$ and $c=18.709(1) \AA ; \mathrm{Cu}_{8} \mathrm{GeS}_{6},{ }^{61}$ orthorhombic space group $P m n 2_{1}$ with refined unit cell parameters $a=7.037(1) \AA, b=6.964(1) \AA$ and $c=9.873(1) \AA$.

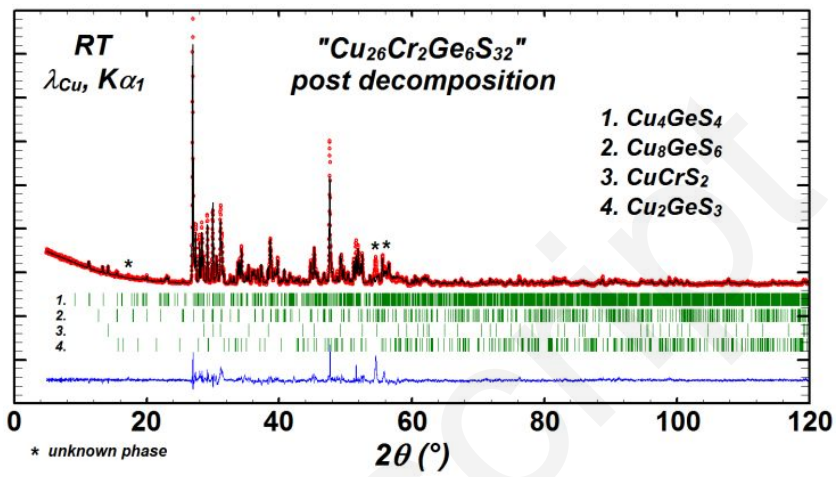

Figure 6. Rietveld refinement of the XRPD pattern recorded at room temperature on sample after thermal treatment showing the nature the phases originating from the decomposition of the colusite $\mathrm{Cu}_{26} \mathrm{Cr}_{2} \mathrm{Ge}_{6} \mathrm{~S}_{32}$ phase: $\mathrm{Cu}_{4} \mathrm{GeS}_{4}$ in its monoclinic form ( $\left.P 2_{1} / c\right), \mathrm{Cu}_{8} \mathrm{GeS}_{6}$ in its low temperature orthorhombic form ( $\left.P m n 2_{1}\right), \mathrm{CuCrS}_{2}$ in its low temperature form $(R 3 m), \mathrm{Cu}_{2} \mathrm{GeS}_{3}$ in its monoclinic form $(C c)$. Symbol * refers to diffraction peaks arising from an unknown phase.

Analysis of the in situ NPD data recorded at higher temperature reveals that the intensity of the diffraction peaks of $\mathrm{CuCrS}_{2}$ and $\mathrm{Cu}_{8} \mathrm{GeS}_{6}$ phases increases progressively up to $\approx 920$ $\mathrm{K}$ (Figure $4 \mathrm{~b}$ ), indicating an increase of their weight fractions in the sample. Concomitantly, the diffraction peaks of the colusite $\mathrm{Cu}_{26} \mathrm{Cr}_{2} \mathrm{Ge}_{6} \mathrm{~S}_{32}$ phase exhibit a rapid decrease in intensity and fully disappear at $920 \mathrm{~K}$. This is evidenced from the thermal evolution of the ( $\left(\begin{array}{lll}4 & 0 & 0\end{array}\right),\left(\begin{array}{lll}4 & 4 & 0\end{array}\right)$ and $\left(\begin{array}{lll}6 & 2 & 2\end{array}\right)$ reflections (Figure $4 \mathrm{~b}$ ), indicating that, above this temperature, the sample does not contain colusite anymore. Interestingly, from $\approx 890 \mathrm{~K}$ up to $920 \mathrm{~K}$, these reflections are splitted into two reflections of relative intensity 2:1 (or 1:2), while the (2 22 ) and (4 4 4) reflections do not evidence any splitting (Figure 4b). Such kind of diffraction peaks splitting suggests modification from a cubic symmetry to a tetragonal symmetry, as already observed in the $\mathrm{Cu}_{22-x} \mathrm{Zn}_{x} \mathrm{Fe}_{8} \mathrm{Ge}_{4} \mathrm{~S}_{32}$ series, where a crossover from the cubic germanite-type structure $(P \overline{4} 3 n$ for $x \leq 0.4)$ to the tetragonal renierite-type structure $(P \overline{4} 2 c$ for $1.2 \leq x \leq 2.0)$ was induced by $\mathrm{Zn}$ for $\mathrm{Cu}$ substitution. ${ }^{29}$ Indeed, the diffraction peaks of this phase can be indexed with tetragonal unit cell of parameters $a=10.776 \AA$ and $c=10.482 \AA$, or $a=5.388 \AA$ and $c=10.484 \AA$. However, the diffraction peaks splitting could also be explained by a cubic to monoclinic modification leading to unit cell parameters $a=6.504 \AA, b=11.418 \AA, c=6.465 \AA$ and $\beta=107.92^{\circ}$. From these results, several crystal structures have been considered and tested: (i) a renierite derivative structure (space group $P \overline{4} 2 c, a=10.776(2) \AA$ and $c=10.482(3)$ $\AA$ ) for which $\mathrm{Fe}$ atoms have been replaced either by $\mathrm{Cu}$ or $\mathrm{Ge}$ atoms, (ii) a briartite derivative $\mathrm{Cu}_{2} \mathrm{FeGeS}_{4}$ structure (space group $I \overline{4} 2 m, a=5.388(1) \AA$ and $c=10.485(3) \AA$ ) for which $\mathrm{Fe}$ atoms have been replaced by $\mathrm{Cu} / \mathrm{Ge}$ atoms, and a chalcopyrite derivative $\mathrm{CuFeS}_{2}$ structure (space group $I \overline{4} 2 d, a=5.388(1) \AA$ and $c=10.484(3) \AA$ ) for which Fe atoms have been replaced by 
Ge atoms (on the basis of the work of Ackermann et al. on the $\mathrm{Ge}$ for $\mathrm{Fe}$ substitution of the $\mathrm{CuFeS}_{2}$ chalcopyrite phase ${ }^{62}$ ), and (iii) the crystal structure of the monoclinic $\mathrm{Cu}_{2} \mathrm{GeS}_{3}$ compound (space group $C c, a=6.504(2) \AA, b=11.418(4) \AA, c=6.465(2)$ $\AA$ and $\left.\beta=107.92(2)^{\circ}\right){ }^{63}$ Rietveld refinements performed with the renierite derivatives crystal structure are slightly worse than those done with the other structural models, allowing to exclude the former. Moreover, from the remaining possible crystal structures, that of the monoclinic $\mathrm{Cu}_{2} \mathrm{GeS}_{3}$ phase leads to a slightly better Rietveld refinement compared to those of the briartite and chalcopyrite derivatives. Consequently, it could be assumed that the phase occurring in the sample above $890 \mathrm{~K}$ from the second step of colusite decomposition is the monoclinic $\mathrm{Cu}_{2} \mathrm{GeS}_{3}$ compound (Figure 5c). It is worth noting that as colusite, its crystal structure is a sphalerite superstructure derivative.

Finally, above $\approx 960 \mathrm{~K}$, the intensity of the diffraction peaks of the $\mathrm{Cu}_{8} \mathrm{GeS}_{6}$ and $\mathrm{Cu}_{2} \mathrm{GeS}_{3}$ phases decreases progressively, while the peaks of the $\mathrm{CuCrS}_{2}$ phase remain almost unchanged, concomitantly with the appearance of new diffraction peaks (labelled with symbol $\S$ in Figure 4c). The latter are characteristic of the monoclinic $\mathrm{Cu}_{4} \mathrm{GeS}_{4}$ phase (space group $P 2_{1} / c$ ), reported to be stable above $605^{\circ} \mathrm{C}$ (i.e. $878 \mathrm{~K}$ ). ${ }^{64}$ The formation of this phase is confirmed by Rietveld refinement of the NPD data recorded at $970 \mathrm{~K}$, leading to the refined unit cell parameters $a=10.051(11) \AA, b=13.365(9) \AA, c=$ 10.033(11) $\AA$, and $\beta=101.36(6)^{\circ}$ (Figure 5d). The XRPD data recorded at room temperature on the sample after thermal treatment leads to the refined unit cell parameters $a=9.812(1)$
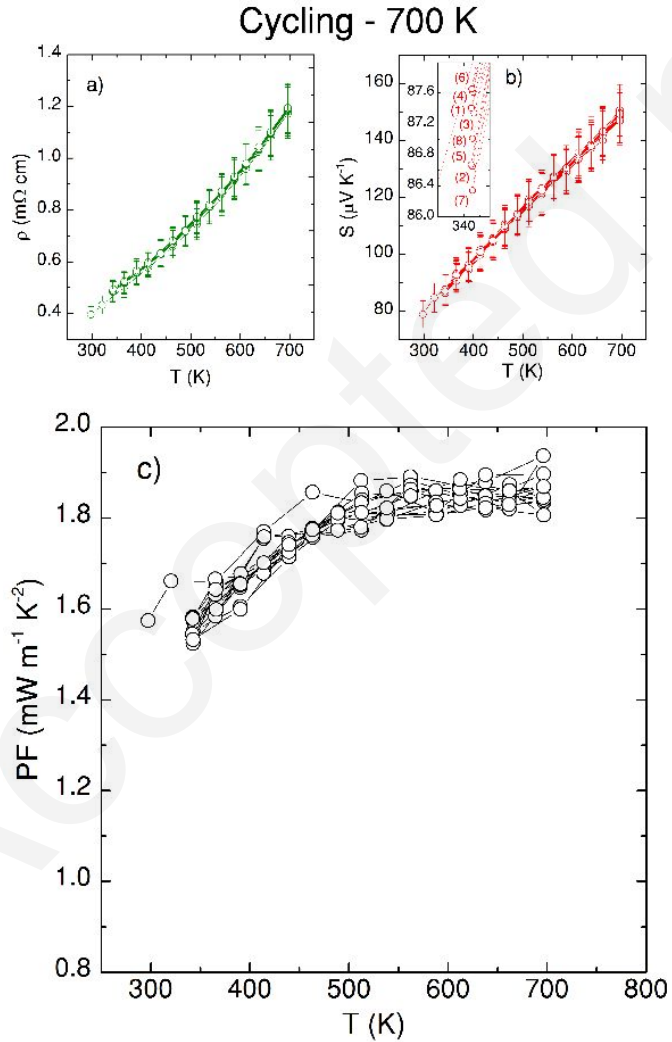

$\AA, b=13.210(1) \AA, c=9.956(1) \AA$, and $\beta=101.00(1)^{\circ}$ (Figure $6)$. The latter result is in apparent contradiction with the two phase transitions expected for this compound at $339 \mathrm{~K}$ and 355 $\mathrm{K},{ }^{64}$ but for which crystal structures have never been reported. Note that in the monoclinic $\mathrm{Cu}_{4} \mathrm{GeS}_{4}$ phase, $\mathrm{Ge}, \mathrm{Cu}$, and $\mathrm{S}$ atoms are respectively located on 2,8 , and 8 crystallographic sites of general multiplicity (i.e. 4 ), all fully occupied. ${ }^{64}$ This induces a complex crystal structure characterized by a threedimensional framework built up of $\mathrm{GeS}_{4}$ tetrahedra sharing corners with $\mathrm{CuS}_{4}$ tetrahedra and $\mathrm{CuS}_{3}$ triangles sharing both corners and edges. ${ }^{64}$ Hence, as with colusites, this sulfide is characterized by the existence of metal-metal interactions.

Temperature cycling influence on the thermoelectric properties. The temperature dependences of the electrical resistivity $(\rho)$ and Seebeck coefficient $(S)$ are displayed in Figure 7 for thermal cycling up to $700 \mathrm{~K}$ and $760 \mathrm{~K}$, respectively. In Figures $7 \mathrm{a}$ and $7 \mathrm{~b}$, seven cycles of heating and cooling performed between $300 \mathrm{~K}$ and $700 \mathrm{~K}$ confirm the stability of the transport properties, in agreement with DSC and diffraction data. The magnitudes of the electrical resistivity and Seebeck coefficient remain stable during the thermal cycles over the entire temperature range. As exemplified in the inset of Figure $7 \mathrm{~b}$, the Seebeck coefficient varies randomly between 86.3 and $87.6 \mu \mathrm{V} \mathrm{K}^{-1}$ at around $340 \mathrm{~K}$. Upon cycling, the power factor is maintained between 1.5 and $1.6 \mathrm{~mW} \mathrm{~m}^{-1} \mathrm{~K}^{-2}$ at $300 \mathrm{~K}$ and between 1.8 and $1.9 \mathrm{~mW} \mathrm{~m}^{-1} \mathrm{~K}^{-2}$ at $700 \mathrm{~K}$ (Figure $7 \mathrm{c}$ ). Note that these values are identical considering the measurement uncertainty.
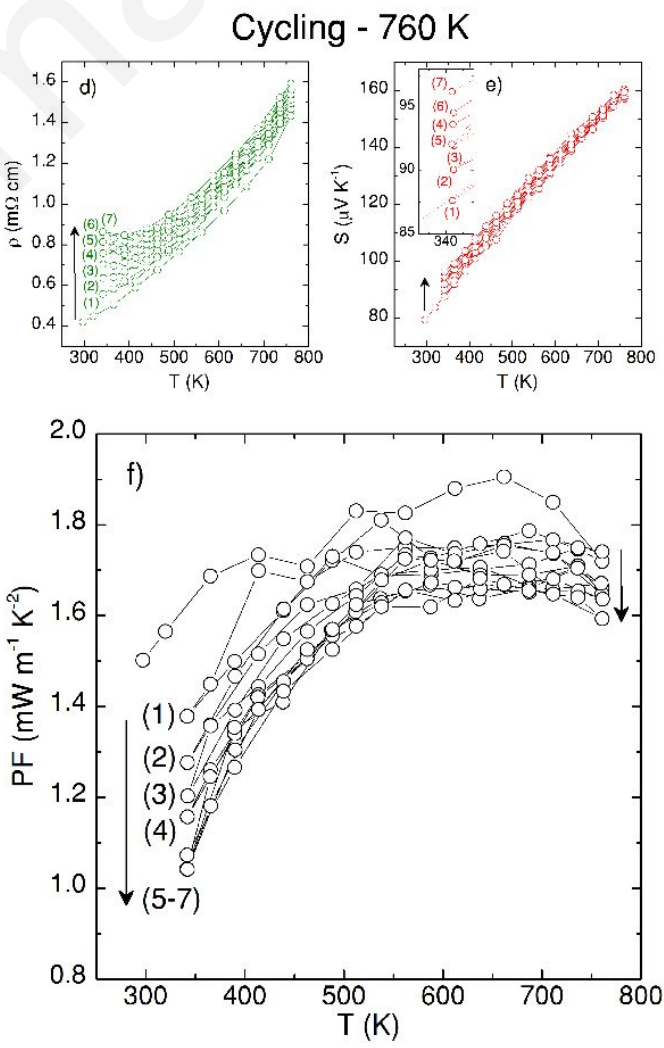

Figure 7. The effect of repeated measurements (7 cycles of heating and cooling) on the electrical resistivity (a, d), Seebeck coefficient (b, e) and power factor (c, f) of $\mathrm{Cu}_{26} \mathrm{Cr}_{2} \mathrm{Ge}_{6} \mathrm{~S}_{32}$; left: from $300 \mathrm{~K}$ to $700 \mathrm{~K}$ and right: from z300 K to $760 \mathrm{~K}$. 
Figures 7d and 7e display the temperature dependences of the electrical resistivity and Seebeck coefficient for thermal cycling between $300 \mathrm{~K}$ and $760 \mathrm{~K}$, respectively. With cycling, a slight shift of both the electrical resistivity and Seebeck coefficient towards higher values can be observed. The electrical resistivity at $340 \mathrm{~K}$ systematically increases from $0.48 \mathrm{~m} \Omega \mathrm{cm}$ in the first heating ramp to around $0.85 \mathrm{~m} \Omega \mathrm{cm}$ in the $7^{\text {th }}$ cycle. Similarly, the Seebeck coefficient increases from $80 \mu \mathrm{V} \mathrm{K}^{-1}$ in the $1^{\text {st }}$ cycle to $96 \mu \mathrm{V} \mathrm{K}^{-1}$ in the $7^{\text {th }}$ cycle. Such behavior likely originates from a decrease in carrier concentration induced by sulfur volatilization above $700 \mathrm{~K}$. Upon cycling, the power factor decreases from $1.6 \mathrm{~mW} \mathrm{~m}^{-1} \mathrm{~K}^{-2}$ to $1.05 \mathrm{~mW} \mathrm{~m}^{-1} \mathrm{~K}^{-2}$ at $340 \mathrm{~K}$ (Figure 7f).

XRD analysis after cycling at $760 \mathrm{~K}$ (Figure 8) confirms that the sample retained high purity (traces of digenite are detected) without significant modification of the colusite unit cell parameter $(a=10.5524(1) \AA$ before cycling and $a=10.5535(1)$ $\AA$ after cycling), suggesting that the sulfur loss remains rather superficial. Interestingly, thermal agitation factors are sensitively smaller than before cycling, which indicates that the repeated cycling process favors the crystallization of the sample. This is easily explained by the relatively short SPS treatment, allowing the subsequent cycling to complete the crystallization.

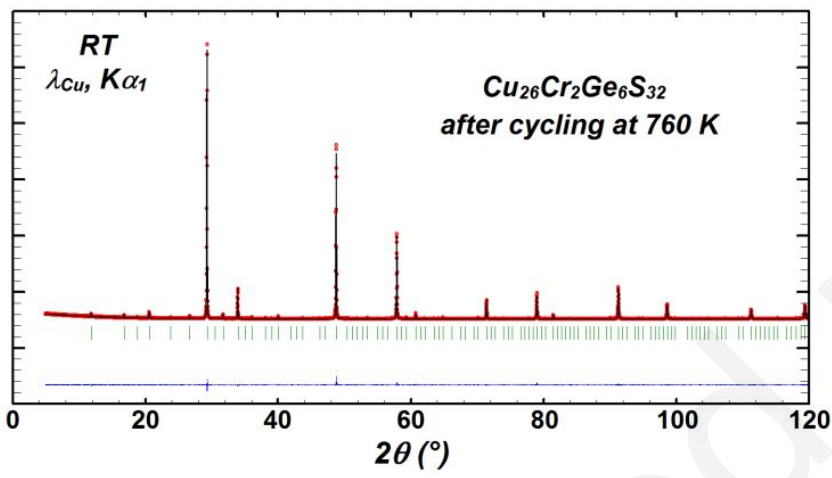

Figure 8. Rietveld refinement of the XRPD pattern recorded at room temperature on sample after cycling at $760 \mathrm{~K}$.

Discussion. In situ NPD measurement recorded at the heating rate of $2 \mathrm{~K} \mathrm{~min}^{-1}$ reveals that the colusite $\mathrm{Cu}_{26} \mathrm{Cr}_{2} \mathrm{Ge}_{6} \mathrm{~S}_{32}$ phase is stable up to $830 \mathrm{~K}$ in a non-oxidative atmosphere (Figure 3 and Figure 4a) and decomposes progressively into $\mathrm{Cu}_{8} \mathrm{GeS}_{6}$ and $\mathrm{CuCrS}_{2}$ phases from this temperature. This first step in colusite $\mathrm{Cu}_{26} \mathrm{Cr}_{2} \mathrm{Ge}_{6} \mathrm{~S}_{32}$ decomposition must induce a germanium enrichment (decrease of the $\mathrm{Cu} / \mathrm{Ge}$ ratio) of the colusite phase, probably responsible for the second step of the decomposition occurring above $880 \mathrm{~K}$ and related to the structural modification from the cubic colusite structure to the monoclinic $\mathrm{Cu}_{2} \mathrm{GeS}_{3}$ structure (Figure 4b). These temperatures are in fair agreement with those corresponding to the maxima of the endothermic peaks detected at $830 \mathrm{~K}$ and $872 \mathrm{~K}$ on the DSC curve recorded at the same heating rate (Figure 1). This two-steps phase decomposition is accompanied by a significant weight loss attributed to sulfur volatilization (Figure 1). Moreover, NPD measurement indicates that the colusite phase $\mathrm{Cu}_{26} \mathrm{Cr}_{2} \mathrm{Ge}_{6} \mathrm{~S}_{32}$ is fully decomposed above $930 \mathrm{~K}$ (Figure $4 \mathrm{~b}$ ), with a weight loss of $\approx 4 \%$ (Figure 1 ), corresponding to $\approx 4$ atoms of sulfur per formula unit. Consequently, these results suggest that colusite $\mathrm{Cu}_{26} \mathrm{Cr}_{2} \mathrm{Ge}_{6} \mathrm{~S}_{32}$ decomposes into $\mathrm{CuCrS}_{2}, \mathrm{Cu}_{8} \mathrm{GeS}_{6}$ and $\mathrm{Cu}_{2} \mathrm{GeS}_{3}$ phases, in association with sulfur volatilization, between $830 \mathrm{~K}$ and $920 \mathrm{~K}$ following the reaction 1 :
$\mathrm{Cu}_{26} \mathrm{Cr}_{2} \mathrm{Ge}_{6} \mathrm{~S}_{32} \rightarrow 2 \mathrm{CuCrS}_{2}+2 \mathrm{Cu}_{8} \mathrm{GeS}_{6}+4 \mathrm{Cu}_{2} \mathrm{GeS}_{3}+4 / x$ $\mathrm{S}_{x}(\mathrm{~g}) \quad$ (reaction 1$)$

Finally, above $960 \mathrm{~K}$, the $\mathrm{Cu}_{8} \mathrm{GeS}_{6}$ and $\mathrm{Cu}_{2} \mathrm{GeS}_{3}$ phases disappear progressively at the expense of the $\mathrm{Cu}_{4} \mathrm{GeS}_{4}$ phase (Figure 4c) without significant sulfur loss (Figure 1), following the reaction 2:

$2 \mathrm{Cu}_{8} \mathrm{GeS}_{6}+4 \mathrm{Cu}_{2} \mathrm{GeS}_{3} \rightarrow 6 \mathrm{Cu}_{4} \mathrm{GeS}_{4} \quad$ (reaction 2)

Even if the phase decomposition of the colusite $\mathrm{Cu}_{26} \mathrm{Cr}_{2} \mathrm{Ge}_{6} \mathrm{~S}_{32}$ starts at around $830 \mathrm{~K}$, the thermal evolution of both electrical resistivity and Seebeck coefficient evidenced by cycling measurements performed up to $760 \mathrm{~K}$ (Figure 7) suggest a modification of the chemical composition of the colusite phase (i.e. sulfur volatilization) a few dozen degrees before phase decomposition. Note that such an evolution of the electrical properties is not observed during cycling measurements up to $700 \mathrm{~K}$ (Figure 7) indicating the high stability of the crystal structure in a non-oxidative atmosphere up to $700 \mathrm{~K}$ and consequently of the high performance thermoelectric properties of $\mathrm{Cu}_{26} \mathrm{Cr}_{2} \mathrm{Ge}_{6} \mathrm{~S}_{32}$ reported in our previous works. ${ }^{39,41} \mathrm{~A}$ rather superficial sulfur loss at $760 \mathrm{~K}$ without decomposition of the colusite $\mathrm{Cu}_{26} \mathrm{Cr}_{2} \mathrm{Ge}_{6} \mathrm{~S}_{32}$ is supported by the detection of a small endothermic signal on the DSC curve above $780 \mathrm{~K}$ as well as weak TGA curve deviation (Figure 1). This superficial sulfur loss likely implies cation over-stoichiometry leading to a metal rich colusite phase with cation occupying initially vacant interstitial crystallographic sites. Moreover, a significant weight loss was evidenced from thermogravimetric measurements in an Ar flow for as-prepared powdered samples of colusites $\mathrm{Cu}_{26} T_{2} \mathrm{Sn}_{6} \mathrm{~S}_{32}$ over the temperature range $550-600 \mathrm{~K}$ for $T=\mathrm{V}$ and $600-650 \mathrm{~K}$ for $T=$ $\mathrm{Nb}$, Ta. ${ }^{34}$ This weight reduction was also assigned to volatilization of a part of sulfur implying a larger metal content in sintered samples (1023 K for $1 \mathrm{~h}$ under $70 \mathrm{MPa}$ ) compared to as-prepared powdered samples. Note that TGA performed on sintered samples do not reveal significant weight loss.

These results show that the colusite $\mathrm{Cu}_{26} \mathrm{Cr}_{2} \mathrm{Ge}_{6} \mathrm{~S}_{32}$ is highly stable up to $700 \mathrm{~K}$ in a non-oxidative atmosphere with a rather superficial sulfur loss around $760 \mathrm{~K}$. The latter leads to crystal structure reorganization and electrical properties evolution without phase decomposition. It is worth noting that these results are obtained from measurements performed under vacuum, which consequently promote sulfur volatilization. On the contrary, sintering processes are performed under an applied pressure of $64 \mathrm{MPa}$ reducing sulfur volatilization and consequently phase decomposition. This explains the high purity pellets prepared by spark plasma sintering even with a sintering temperature of $873 \mathrm{~K} .{ }^{39}$

As with the electrical properties, the superficial sulfur loss between $760 \mathrm{~K}$ and $830 \mathrm{~K}$ seems to slowly modify the crystal structure of the colusite $\mathrm{Cu}_{26} \mathrm{Cr}_{2} \mathrm{Ge}_{6} \mathrm{~S}_{32}$. Indeed, no abrupt structural evolution is detected from NPD as evidenced by the almost linear thermal evolution of the refined unit cell parameter of $\mathrm{Cu}_{26} \mathrm{Cr}_{2} \mathrm{Ge}_{6} \mathrm{~S}_{32}$ from $573 \mathrm{~K}$ up to $830 \mathrm{~K}$ (Figure 3 ). From these data, the thermal linear expansion coefficient $\alpha_{L}$ can be estimated to be $28.9 \times 10^{-6} \mathrm{~K}^{-1}$ for $\mathrm{Cu}_{26} \mathrm{Cr}_{2} \mathrm{Ge}_{6} \mathrm{~S}_{32}$, a value calculated from the relation $\Delta L / L=\alpha_{L} \Delta T$ by using a linear fitting of the unit cell parameter between $573 \mathrm{~K}$ and $830 \mathrm{~K}(27$ points, $\mathrm{R}^{2}=0.9810$ ) determined from Rietveld refinements of the NPD data. Note that this value is significantly higher than those of $\approx 16.9 \times 10^{-6} \mathrm{~K}^{-1}$ reported for $\mathrm{Cu}_{26} \mathrm{Nb}_{2} \mathrm{Ge}_{6} \mathrm{~S}_{32}$ between $293 \mathrm{~K}$ and $573 \mathrm{~K},{ }^{40}$ and $17.5 \times 10^{-6} \mathrm{~K}^{-1}$ calculated for 
$\mathrm{Cu}_{26} \mathrm{~V}_{2} \mathrm{Sn}_{6} \mathrm{~S}_{32}$ between $300 \mathrm{~K}$ and $650 \mathrm{~K}$, both determined on a lower temperature interval.

As with $\mathrm{Cu}_{26} \mathrm{Cr}_{2} \mathrm{Ge}_{6} \mathrm{~S}_{32}$, we have estimated the thermal linear expansion coefficient $\alpha_{L}$ of $\mathrm{Cu}_{26} \mathrm{~V}_{2} \mathrm{Ge}_{6} \mathrm{~S}_{32}$ at high temperature (between $600 \mathrm{~K}$ and $1000 \mathrm{~K}$ ) from the thermal evolution of its unit cell parameter determined from Rietveld refinements of the NPD data (Figure 9). However, during warming the thermal evolution of the refined unit cell parameter of $\mathrm{Cu}_{26} \mathrm{~V}_{2} \mathrm{Ge}_{6} \mathrm{~S}_{32}$ deviates significantly from the linearity hindering the determination of only one thermal linear expansion coefficient. Indeed, an almost linear thermal evolution is observed between $600 \mathrm{~K}$ and $830 \mathrm{~K}\left(\alpha_{L 600 \mathrm{~K}}^{830 \mathrm{~K}}=24.8 \times 10^{-6} \mathrm{~K}^{-1}, \mathrm{~N}=24, \mathrm{R}^{2}=\right.$ 0.9856 ), followed by an important increase of the $a$ parameter between $830 \mathrm{~K}$ and $930 \mathrm{~K}\left(\alpha_{L} 930 \mathrm{~K} K=60.1 \times 10^{-6} \mathrm{~K}^{-1}, \mathrm{~N}=11\right.$, $\mathrm{R}^{2}=0.9924$ ) before slowing down, between $930 \mathrm{~K}$ and $1000 \mathrm{~K}$, to a thermal evolution close to that observed between $600 \mathrm{~K}$ and $830 \mathrm{~K}\left(\alpha_{L} 1000 \mathrm{~K}=25.7 \times 10^{-6} \mathrm{~K}^{-1}, \mathrm{~N}=8, \mathrm{R}^{2}=0.9718\right)$. By considering that the colusite $\mathrm{Cu}_{26} \mathrm{Cr}_{2} \mathrm{Ge}_{6} \mathrm{~S}_{32}$ is characterized by (i) a superficial sulfur loss between $760 \mathrm{~K}$ and $830 \mathrm{~K}$ without phase decomposition and (ii) a thermal linear expansion coefficient below $830 \mathrm{~K}$ of the same order as that of $\mathrm{Cu}_{26} \mathrm{~V}_{2} \mathrm{Ge}_{6} \mathrm{~S}_{32}$ on the same temperature range, it is reasonable to attribute the nonlinear evolution of the thermal expansion of $\mathrm{Cu}_{26} \mathrm{~V}_{2} \mathrm{Ge}_{6} \mathrm{~S}_{32}$ observed at high temperature to sulfur volatilization. This is supported by the larger unit cell parameter of $\mathrm{Cu}_{26} \mathrm{~V}_{2} \mathrm{Ge}_{6} \mathrm{~S}_{32}$ refined from NPD data recorded at room temperature after the thermal treatment $(a=10.645(1) \AA)$ compared to that refined before the thermal treatment $(a=$ $10.574(1) \AA$ ). Indeed, a similar trend was already observed in $\mathrm{Cu}_{26} \mathrm{~V}_{2} \mathrm{Sn}_{6} \mathrm{~S}_{32}$, for which a sample sintered at $1023 \mathrm{~K}$ was characterized by a larger unit cell parameter than that refined on a sample sintered at $873 \mathrm{~K} .{ }^{36}$ This difference of cell parameter value was explained by sulfur volatilization promoted by high temperature sintering (i.e. $1023 \mathrm{~K}$ instead of $873 \mathrm{~K}$ ), and subsequently leading to a sample with point defects and disordered regions. ${ }^{36}$ As with $\mathrm{Cu}_{26} \mathrm{~V}_{2} \mathrm{Sn}_{6} \mathrm{~S}_{32}$, the modification of the colusite $\mathrm{Cu}_{26} \mathrm{~V}_{2} \mathrm{Ge}_{6} \mathrm{~S}_{32}$ structure should be expected during warming through sulfur volatilization explaining the nonlinear evolution of its thermal expansion. Nevertheless, artifact from incomplete crystallization of the colusite phase during the fast SPS process cannot be excluded.

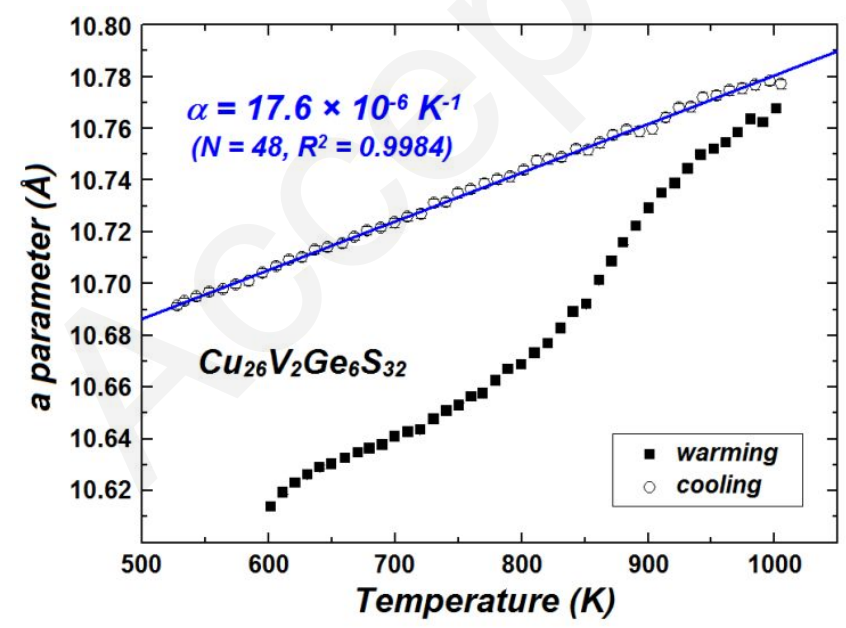

Figure 9. Thermal evolution of the $\mathrm{Cu}_{26} \mathrm{~V}_{2} \mathrm{Ge}_{6} \mathrm{~S}_{32}$ colusite unit cell parameter determined from Rietveld refinements of the NPD data during warming and cooling. Blue line corresponds to the linear fit (see text).
Conversely, the thermal evolution of the a parameter of $\mathrm{Cu}_{26} \mathrm{~V}_{2} \mathrm{Ge}_{6} \mathrm{~S}_{32}$ during cooling is perfectly linear over the whole temperature range (Figure 9) and leads to thermal linear expansion coefficient $\alpha_{L}$ of $17.6 \times 10^{-6} \mathrm{~K}^{-1}\left(\mathrm{~N}=48, \mathrm{R}^{2}=\right.$ $0.9984)$, a value close to those reported for $\mathrm{Cu}_{26} \mathrm{Nb}_{2} \mathrm{Ge}_{6} \mathrm{~S}_{32}$ and $\mathrm{Cu}_{26} \mathrm{~V}_{2} \mathrm{Sn}_{6} \mathrm{~S}_{32}$. The value of the unit cell parameter determined from the extrapolation to $300 \mathrm{~K}$ of the linear fit of refined unit cell parameter of $\mathrm{Cu}_{26} \mathrm{~V}_{2} \mathrm{Ge}_{6} \mathrm{~S}_{32}$ during cooling ( $a=10.649 \AA$ ) is very close to that determined experimentally ( $a=10.645(1)$ $\AA$ ) from Rietveld refinement of the NPD pattern recorded at room temperature after thermal treatment. This suggests that the crystal structure modification induced during thermal treatment up to $1000 \mathrm{~K}$ is stable down to room temperature. Note that potential copper mobility at high temperature, responsible for the nonlinear thermal evolution of the cell parameter in copperrich tetrahedrite, ${ }^{65}$ is excluded by the irreversibility of the phenomenon during cooling. Consequently, the structural modification induced by superficial sulfur volatilization should lead to different electrical and thermal properties, and subsequently thermoelectric performance, of $\mathrm{Cu}_{26} \mathrm{~V}_{2} \mathrm{Ge}_{6} \mathrm{~S}_{32}$, as already shown for $\mathrm{Cu}_{26} \mathrm{~V}_{2} \mathrm{Sn}_{6} \mathrm{~S}_{32}$ sintered at different temperatures. ${ }^{36}$ Such characterizations are in progress.

Finally, the colusite $\mathrm{Cu}_{26} \mathrm{~V}_{2} \mathrm{Ge}_{6} \mathrm{~S}_{32}$ is stable (no phase decomposition) up to at least $1000 \mathrm{~K}$ (Figure 2), a temperature well above that of the limit of stability of the colusite $\mathrm{Cu}_{26} \mathrm{Cr}_{2} \mathrm{Ge}_{6} \mathrm{~S}_{32}$ for which the phase decomposition starts at 840 $\mathrm{K}$ (Figure 4a). This indicates that the replacement of pentavalent $\mathrm{V}^{5+}$ cations by hexavalent $\mathrm{Cr}^{6+}$ cations not only strongly influences the thermoelectric properties ${ }^{39}$ but also the high temperature stability of the colusite phase. As a consequence, a reduction of the thermal conductivity in order to enhance thermoelectric performance through process controlled structural disordering at high temperature will be strongly limited for $\mathrm{Cu}_{26} \mathrm{Cr}_{2} \mathrm{Ge}_{6} \mathrm{~S}_{32}$ and more attainable for $\mathrm{Cu}_{26} \mathrm{~V}_{2} \mathrm{Ge}_{6} \mathrm{~S}_{32}$. Other strategies must be investigated to induce structural disorder in $\mathrm{Cu}_{26} \mathrm{Cr}_{2} \mathrm{Ge}_{6} \mathrm{~S}_{32}$ while maintaining its structural integrity.

\section{CONCLUSION}

In this work, we have investigated the effect of temperature on the crystal structure and electrical properties stability of the high thermoelectric performance colusite $\mathrm{Cu}_{26} \mathrm{Cr}_{2} \mathrm{Ge}_{6} \mathrm{~S}_{32}$. The results indicate a high stability of $\mathrm{Cu}_{26} \mathrm{Cr}_{2} \mathrm{Ge}_{6} \mathrm{~S}_{32}$ up to at least $700 \mathrm{~K}$ in a non-oxidative atmosphere. Above $\approx 760 \mathrm{~K}$ a rather superficial sulfur loss without phase decomposition is evidenced, leading to a crystal structure modification through cation over-stoichiometry. Above $830 \mathrm{~K}$, the colusite $\mathrm{Cu}_{26} \mathrm{Cr}_{2} \mathrm{Ge}_{6} \mathrm{~S}_{32}$ phase evidences a two-steps decomposition reaction leading to the formation of $\mathrm{Cu}_{8} \mathrm{GeS}_{6}, \mathrm{CuCrS}_{2}$ and $\mathrm{Cu}_{2} \mathrm{GeS}_{3}$ phases as well as a significant sulfur volatilization of $\approx 4$ atoms per formula unit. The colusite $\mathrm{Cu}_{26} \mathrm{Cr}_{2} \mathrm{Ge}_{6} \mathrm{~S}_{32}$ phase is fully decomposed above $930 \mathrm{~K}$. Moreover, we show that $\mathrm{Cu}_{26} \mathrm{~V}_{2} \mathrm{Ge}_{6} \mathrm{~S}_{32}$ is stable (no phase decomposition) up to $1000 \mathrm{~K}$, a temperature well above the limit of stability of $\mathrm{Cu}_{26} \mathrm{Cr}_{2} \mathrm{Ge}_{6} \mathrm{~S}_{32}$. This indicates a non-negligible effect of pentavalent $\mathrm{V}^{5+}$ by hexavalent $\mathrm{Cr}^{6+}$ substitution, not only on the thermoelectric properties, but also on the chemical bonding of this family of material. The direct consequence of this substitution is the difficulty to reduce the thermal conductivity, and subsequently, to enhance the thermoelectric performance of colusite $\mathrm{Cu}_{26} \mathrm{Cr}_{2} \mathrm{Ge}_{6} \mathrm{~S}_{32}$ through process-controlled structural disordering at high temperature. 


\section{AUTHOR INFORMATION}

\section{Corresponding author}

*(P. Lemoine) E-mail: pierric.lemoine@univ-rennes1.fr

\section{ACKNOWLEDGMENTS}

The authors gratefully thank Laura Paradis-Fortin and Sofien Djellit for technical support and are indebted to the Institut Laue Langevin (Grenoble, France) for the provision of research facilities (doi:10.5291/ILL-DATA.5-24-615). This work was supported by the French Agence Nationale de la Recherche (ANR) through the program Energy Challenge for Secure, Clean and Efficient Energy (Challenge 2, 2015, ANR-15-CE05-0027), FEDER and Normandy Region.

\section{REFERENCES}

(1) Qiu, P.; Zhang, T.; Qiu, Y.; Shi, X.; Chen, L. Sulfide bornite thermoelectric material: a natural mineral with ultralow thermal conductivity. Energy Environ. Sci. 2014, 7, 4000-4006.

(2) Guélou, G.; Powell, A. V.; Vaqueiro, P. Ball milling as an effective route for the preparation of doped bornite: synthesis, stability and thermoelectric properties. J. Mater. Chem. C 2015, 3, 1062410629.

(3) Pavan Kumar, V.; Barbier, T.; Lemoine, P.; Raveau, B.; Nassif, V.; Guilmeau, E. The crucial role of selenium for sulphur substitution in the structural transitions and thermoelectric properties of $\mathrm{Cu}_{5} \mathrm{FeS}_{4}$ bornite. Dalton Trans. 2017, 46, 2174-2183.

(4) Long, S. O. J.; Powell, A. V.; Vaqueiro, P.; Hull, S. High thermoelectric performance of bornite through control of the $\mathrm{Cu}(\mathrm{II})$ content and vacancy concentration. Chem. Mater. 2018, 30, 456-464.

(5) Zhang, A.; Zhang, B.; Lu, W.; Xie, D.; Ou, H.; Han, X.; Dai, J.; Lu, X.; Han, G.; Wang, G.; Zhou, X. Twin engineering in solutionsynthesized nonstoichiometric $\mathrm{Cu}_{5} \mathrm{FeS}_{4}$ icosahedral nanoparticles for enhanced thermoelectric performance. Adv. Funct. Mater. 2018, 28, 1705117.

(6) Ostovari Moghaddam, A.; Shokuhfar, A.; Cabot, A. Thermoelectric properties of nanostructured bornite $\mathrm{Cu}_{5-\mathrm{x}} \mathrm{Co}_{\mathrm{x}} \mathrm{FeS}_{4}$ synthesized by high energy ball milling. J. Alloys Compd. 2018, 750, $1-7$.

(7) Ostovari Moghaddam, A.; Shokuhfar, A.; Guardia, P.; Zhang, Y.; Cabot, A. Substantial role of doping in the thermoelectric and hardness properties of nanostructured bornite, $\mathrm{Cu}_{5} \mathrm{FeS}_{4}$. J. Alloys Compd. 2019, 773, 1064-1074.

(8) Barbier, T.; Berthebaud, D.; Frésard, R.; Lebedev, O. I.; Guilmeau, E.; Eyert, V.; Maignan, A. Structural and thermoelectric properties of n-type isocubanite $\mathrm{CuFe}_{2} \mathrm{~S}_{3}$. Inorg. Chem. Front. 2017, 4, 424-432.

(9) Chen, K.; Du, B.; Bonini, N.; Weber, C.; Yan, H.; Reece, M. J. Theory-guided synthesis of an eco-friendly and low-cost copper based sulfide thermoelectric material. J. Phys. Chem. C 2016, 120, 2713527140 .

(10) Chen, K.; Di Paola, C.; Du, B.; Zhang, R.; Laricchia, S.; Bonini, N.; Weber, C.; Abrahams, I.; Yan, H.; Reece, M. Enhanced thermoelectric performance of Sn-doped $\mathrm{Cu}_{3} \mathrm{SbS}_{4}$. J. Mater. Chem. C 2018, 6, 8546-8552.

(11) Tan, Q.; Sun, W.; Li, Z.; Li, J.-F. Enhanced thermoelectric properties of earth-abundant $\mathrm{Cu}_{2} \mathrm{SnS}_{3}$ via In doping effect. J. Alloys Compd. 2016, 672, 558-563.

(12) Shen, Y.; Li, C.; Huang, R.; Tian, R.; Ye, Y.; Pan, L.; Koumoto, K.; Zhang, R.; Wan, C.; Wang, Y. Eco-friendly p-type $\mathrm{Cu}_{2} \mathrm{SnS}_{3}$ thermoelectric material: crystal structure and transport properties. Sci. Rep. 2016, 6, 32501.

(13) Zhao, H.; Xu, X.; Li, C.; Tian, R.; Zhang, R.; Huang, R.; Lyu, Y.; Li, D.; Hu, X.; Pan, L.; Wang, Y. Cobalt-doping in $\mathrm{Cu}_{2} \mathrm{SnS}_{3}$ : enhanced thermoelectric performance by synergy of phase transition and band structure modification. J. Mater. Chem. A 2017, 5, 2326723275.

(14) Goto, Y.; Naito, F.; Sato, R.; Yoshiyasu, K.; Itoh, T.; Kamihara, Y.; Matoba, M. Enhanced thermoelectric figure of merit in stannite- kuramite solid solutions $\mathrm{Cu}_{2+\mathrm{x}} \mathrm{Fe}_{1-\mathrm{x}} \mathrm{SnS}_{4-\mathrm{y}}(\mathrm{x}=0-1)$ with anisotropy lowering. Inorg. Chem. 2013, 52, 9861-9866.

(15) Yang, Y.; Ying, P.; Wang, J.; Liu, X.; Du, Z.; Chao, Y.; Cui, J. Enhancing the thermoelectric performance of $\mathrm{Cu}_{3} \mathrm{SnS}_{4}$-based solid solutions through coordination of the Seebeck coefficient and carrier concentration. J. Mater. Chem. A 2017, 5, 18808-18815.

(16) Liu, M.-L.; Huang, F.-Q.; Chen, L.-D.; Chen, I-W. A wideband-gap p-type thermoelectric material based on quaternary chalcogenides of $\mathrm{Cu}_{2} \mathrm{ZnSnQ}_{4}(\mathrm{Q}=\mathrm{S}, \mathrm{Se})$. Appl. Phys. Lett. 2009, 94 , 202103.

(17) Zhang, R.; Chen, K.; Du, B.; Reece, M. J. Screening for Cu-S based thermoelectric materials using crystal structure features. $J$. Mater. Chem. A 2017, 5, 5013-5019.

(18) Pavan Kumar, V.; Barbier, T.; Caignaert, V.; Raveau, B.; Daou, R.; Malaman, B.; Le Caër, G.; Lemoine, P.; Guilmeau, E. Copper hyper-stoichiometry: the key for the optimization of thermoelectric properties in stannoidite $\mathrm{Cu}_{8+\mathrm{x}} \mathrm{Fe}_{3-\mathrm{x}} \mathrm{Sn}_{2} \mathrm{~S}_{12}$. J. Phys. Chem. C 2017, 121, 16454-16461.

(19) Suekuni, K.; Tsuruta, K.; Ariga, T.; Koyano, M. Thermoelectric properties of mineral tetrahedrites $\mathrm{Cu}_{10} \mathrm{Tr}_{2} \mathrm{Sb}_{4} \mathrm{~S}_{13}$ with low thermal conductivity. Appl. Phys. Express 2012, 5, 051201.

(20) Suekuni, K.; Tsuruta, K.; Kunii, M.; Nishiate, H.; Nishibori, E.; Maki, S.; Ohta, M.; Yamamoto, A.; Koyano, M. High-performance thermoelectric mineral $\mathrm{Cu}_{12-\mathrm{x}} \mathrm{Ni}_{\mathrm{x}} \mathrm{Sb}_{4} \mathrm{~S}_{13}$ tetrahedrite. J. Appl. Phys. 2013, 113, 043712 .

(21) Lu, X.; Morelli, D. T.; Xia, Y.; Zhou, F.; Ozolins, V.; Chi, H.; Zhou, X.; Uher, C. High performance thermoelectricity in earthabundant compounds based on natural mineral tetrahedrites. Adv. Energy Mater. 2013, 3, 342-348.

(22) Lu, X.; Morelli, D. T. Natural mineral tetrahedrite as a direct source of thermoelectric materials. Phys. Chem. Chem. Phys. 2013, 15, $5762-5766$.

(23) Barbier, T.; Lemoine, P.; Gascoin, S.; Lebedev, O. I.; Kaltzoglou, A.; Vaqueiro, P.; Powell, A. V.; Smith, R. I.; Guilmeau, E. Structural stability of the synthetic thermoelectric ternary and nickelsubstituted tetrahedrite phases. J. Alloys Compd. 2015, 634, 253-262.

(24) Lu, X.; Morelli, D. T.; Xia, Y.; Ozolins, V. Increasing the thermoelectric figure of merit of tetrahedrites by co-doping with nickel and zinc. Chem. Mater. 2015, 27, 408-413.

(25) Barbier, T.; Lemoine, P.; Martinet, S.; Eriksson, M.; Gilmas, M.; Hug, E.; Guélou, G.; Vaqueiro, P.; Powell, A. V.; Guilmeau, E. Up-scaled synthesis process of sulphur-based thermoelectric materials. RSC Adv. 2016, 6, 10044-10053.

(26) Bouyrie, Y.; Sassi, S.; Candolfi, C.; Vaney, J.-B.; Dauscher, A.; Lenoir, B. Thermoelectric properties of double-substituted tetrahedrites $\mathrm{Cu}_{12-\mathrm{x}} \mathrm{Co}_{\mathrm{x}} \mathrm{Sb}_{4-\mathrm{y}} \mathrm{Te}_{\mathrm{y}} \mathrm{S}_{13}$. Dalton Trans. 2016, 45, 7294 7302 .

(27) Levinsky, P.; Candolfi, C.; Dauscher, A.; Lenoir, B.; Hejtmánek, J. Thermoelectric properties of magnesium-doped tetrahedrite $\mathrm{Cu}_{12-\mathrm{x}} \mathrm{Mg}_{\mathrm{x}} \mathrm{Sb}_{4} \mathrm{~S}_{13}$. J. Electron. Mater. 2019, 48, 1926-1931.

(28) Pavan Kumar, V.; Paradis-Fortin, L.; Lemoine, P.; Caignaert, V.; Raveau, B.; Malaman, B.; Le Caër, G.; Cordier, S.; Guilmeau, E. Designing a thermoelectric copper-rich sulfide from a natural mineral: synthetic germanite $\mathrm{Cu}_{22} \mathrm{Fe}_{8} \mathrm{Ge}_{4} \mathrm{~S}_{32}$. Inorg. Chem. 2017, 56, 1337613381.

(29) Pavan Kumar, V.; Paradis-Fortin, L.; Lemoine, P.; Le Caër, G.; Malaman, B.; Boullay, P.; Raveau, B.; Guélou, G.; Guilmeau, E. Crossover from germanite to renierite-type structures in $\mathrm{Cu}_{22}$ ${ }_{x} \mathrm{Zn}_{\mathrm{x}} \mathrm{Fe}_{8} \mathrm{Ge}_{4} \mathrm{~S}_{32}$ thermoelectric sulfides ACS Appl. Energy Mater. 2019 , 2, 7679-7689.

(30) Suekuni, K.; Kim, F. S.; Takabatake, T. Tunable electronic properties and low thermal conductivity in synthetic colusites $\mathrm{Cu}_{26}$ ${ }_{\mathrm{x}} \mathrm{Zn}_{\mathrm{x}} \mathrm{V}_{2} \mathrm{M}_{6} \mathrm{~S}_{32}(\mathrm{x} \leq 4, \mathrm{M}=\mathrm{Ge}, \mathrm{Sn})$. J. Appl. Phys. 2014, 116, 063706.

(31) Suekuni, K.; Kim, F. S.; Nishiate, H.; Ohta, M.; Tanaka, H. I.; Takabatake, T. High-performance thermoelectric minerals: colusites $\mathrm{Cu}_{26} \mathrm{~V}_{2} \mathrm{M}_{6} \mathrm{~S}_{32}(\mathrm{M}=\mathrm{Ge}, \mathrm{Sn})$. Appl. Phys. Lett. 2014, 105, 132107.

(32) Bourgès, C.; Gilmas, M.; Lemoine, P.; Mordvinova, N. E.; Lebedev, O. I.; Hug, E.; Nassif, V.; Malaman, B.; Daou, R.; Guilmeau, E. Structural analysis and thermoelectric properties of mechanically alloyed colusites. J. Mater. Chem. C 2016, 4, 7455-7463. 
(33) Kim, F. S.; Suekuni, K.; Nishiate, H.; Ohta, M.; Tanaka, H. I.; Takabatake, T. Tuning the charge carrier density in the thermoelectric colusite. J. Appl. Phys. 2016, 119, 175105.

(34) Kikuchi, Y.; Bouyrie, Y.; Ohta, M.; Suekuni, K.; Aihara, M.; Takabatake, T. Vanadium-free colusites $\mathrm{Cu}_{26} \mathrm{~A}_{2} \mathrm{Sn}_{6} \mathrm{~S}_{32}(\mathrm{~A}=\mathrm{Nb}, \mathrm{Ta})$ for environmentally friendly thermoelectrics. J. Mater. Chem. A 2016, 4, 15207.

(35) Bouyrie, Y.; Ohta, M.; Suekuni, K.; Kikuchi, Y.; Jood, P.; Yamamoto, A.; Takabatake, T. Enhancement in the thermoelectric performance of colusites $\mathrm{Cu}_{26} \mathrm{~A}_{2} \mathrm{E}_{6} \mathrm{~S}_{32}(\mathrm{~A}=\mathrm{Nb}, \mathrm{Ta} ; \mathrm{E}=\mathrm{Sn}, \mathrm{Ge})$ using E-site non-stoichiometry. J. Mater. Chem. C 2017, 5, 4174-4184.

(36) Bourgès, C.; Bouyrie, Y.; Supka, A. R.; Al Rahal Al Orabi, R.; Lemoine, P.; Lebedev, O. I.; Ohta, M.; Suekuni, K.; Nassif, V.; Hardy, V.; Daou, R.; Miyazaki, Y.; Fornari, M.; Guilmeau, E. Highperformance thermoelectric bulk colusite by process controlled structural disordering. J. Am. Chem. Soc. 2018, 140, 2186-2195.

(37) Bouyrie, Y.; Ohta, M.; Suekuni, K.; Jood, P.; Takabatake, T. Addition of $\mathrm{Co}, \mathrm{Ni}, \mathrm{Fe}$ and their role in the thermoelectric properties of colusite $\mathrm{Cu}_{26} \mathrm{Nb}_{2} \mathrm{Ge}_{6} \mathrm{~S}_{32}$. J. Alloys Compd. 2018, 735, 1838-1845.

(38) Suekuni, K.; Shimizu, Y.; Nishibori, E.; Kasai, H.; Saito, H.; Yoshimoto, D.; Hashikuni, K.; Bouyrie, Y.; Chetty, R.; Ohta, M.; Guilmeau, E.; Takabatake, T.; Watanabe, K.; Ohtaki, M. Atomic-scale phonon scatterers in thermoelectric colusites with a tetrahedral framework structure. J. Mater. Chem. A 2019, 7, 228-235.

(39) Pavan Kumar, V.; Supka, A. R.; Lemoine, P.; Lebedev, O. I.; Raveau, B.; Suekuni, K.; Nassif, V.; Al Rahal Al Orabi, R.; Fornari, M.; Guilmeau, E. High power factors of thermoelectric colusites $\mathrm{Cu}_{26} \mathrm{~T}_{2} \mathrm{Ge}_{6} \mathrm{~S}_{32}(\mathrm{~T}=\mathrm{Cr}$, Mo, W): toward functionalization of the conductive "Cu-S" network. Adv. Energy Mater. 2019, 9, 1803249.

(40) Chetty, R.; Kikuchi, Y.; Bouyrie, Y.; Jood, P.; Yamamoto, A.; Suekuni, K.; Ohta, M. Power generation from the $\mathrm{Cu}_{26} \mathrm{Nb}_{2} \mathrm{Ge}_{6} \mathrm{~S}_{32^{-}}$ based single thermoelectric element with Au diffusion barrier. J. Mater. Chem. C 2019, 7, 5184-5192.

(41) Pavan Kumar, V.; Guélou, G.; Lemoine, P.; Raveau, B.; Supka, A. R.; Al Rahal Al Orabi, R.; Fornari, M.; Suekuni, K.; Guilmeau, E. Copper-rich thermoelectric sulfides: size-mismatch effect and chemical disorder in the $\left[\mathrm{TS}_{4}\right] \mathrm{Cu}_{6}$ complexes of $\mathrm{Cu}_{26} \mathrm{~T}_{2} \mathrm{Ge}_{6} \mathrm{~S}_{32}(\mathrm{~T}=\mathrm{Cr}$, Mo, W) colusites. Angew. Chem. Int. Ed. 2019, 58, 15455-15463.

(42) Binnie, W. P.; Redman, M. J.; Mallio, W. J. On the preparation, properties, and structure of cuprous ammonium thiomolybdate. Inorg. Chem. 1970, 9, 1449-1452.

(43) Raymond, C. C.; Dorhout, P. K.; Miller, S. M. Crystal structure of dicaesium tetrathiomolybdate, $\mathrm{Cs}_{2} \mathrm{MoS}_{4}$. Z. Kristallogr. 1995, 210 , 775 .

(44) Ellermeier, J.; Näther, C.; Bensch, W. $\mathrm{Rb}_{2} \mathrm{MoS}_{4}$. Acta Cryst. C 1999, 55, 1748-1751.

(45) Emirdag-Eanes, M.; Ibers, J. A. Crystal structure of dipotassium tetrathiomolybdate, $\mathrm{K}_{2} \mathrm{MoS}_{4}$. Z. Kristallogr. New Cryst. Struct. 2001, $216,484$.

(46) Sasvári, K. The crystal structure of ammonium thiotungstate $\left(\mathrm{NH}_{4}\right)_{2} \mathrm{WS}_{4}$. Acta Cryst. 1963, 16, 719-724.

(47) Harris, D. C.; Roberts, A. C.; Thorpe, R. I.; Criddle, A. J.; Stanley, C. J. Kiddcreekite, a new mineral from the Kidd Creek mine, Timmins, Ontario, and from the Campbell orebody, Bisbee, Arizona. Can. Mineral. 1984, 22, 227-232.
(48) Pruss, E. A.; Snyder, B. S.; Stacy, A. M. A new layered ternary sulfide: formation of $\mathrm{Cu}_{2} \mathrm{WS}_{4}$ by reaction of $\mathrm{WS}_{4}{ }^{2-}$ and $\mathrm{Cu}^{+}$ions Angew. Chem. Int. Ed. Engl. 1993, 32, 256-257.

(49) Yao, J.; Ibers, J. A. Dirubidium tetrathiotungstate, $\mathrm{Rb}_{2}\left[\mathrm{WS}_{4}\right]$. Acta Cryst. E 2004, 60, i10-i11.

(50) Putz, H.; Paar, W. H.; Topa, D.; Makovicky, E.; Roberts, A. C. Catamarcaite, $\mathrm{Cu}_{6} \mathrm{GeWS}_{8}$, a new germanium sulfide mineral species from Capillitas, Catamarca, Argentina: description, paragenesis and crystal structure. Can. Mineral. 2006, 44, 1481-1497.

(51) Srinivasan, B. R.; Näther, C.; Bensch, W. $\mathrm{Cs}_{2}\left[\mathrm{WS}_{4}\right]$. Acta Cryst. E 2007, 63, i167.

(52) Liu, W.; Dong, C.; Gu, X.; Liu, Y.; Qiu, X.; Chen, Y. The crystal structure of kiddcreekite solved using micro X-ray diffraction and the EPCryst program. Mineral. Mag. 2014, 78, 1517-1525.

(53) Rodriguez-Carvajal, J. Recent advances in magnetic structure determination by neutron powder diffraction. Physica B 1993, 192, 5559.

(54) Roisnel, T.; Rodriguez-Carvajal, J. WinPLOTR: a windows tool for powder diffraction pattern analysis. Mater. Sci. Forum 2001, $378-381,118-123$.

(55) Frank Kamenetskaya, O. V.; Rozhdestvenskaya, I. V.; Yanulova, L. A. New data on the crystal structures of colusites and arsenosulvanites. J. Struct. Chem. 2002, 43, 89-100.

(56) Le Nagard, N.; Collin, G.; Gorochov, O. Etude structurale et propriétés physiques de $\mathrm{CuCrS}_{2}$. Mater. Res. Bull. 1979, 14, 14111417.

(57) Kuhs, W. F.; Nitsche, R.; Scheunemann, K. The argyrodites - a new family of tetrahedrally close-packed structures. Mat. Res. Bull. 1979, 14, 241-248.

(58) Aliev, M. I.; Dzhabrailov, T. G.; Arasly, D. G.; Ragimov, R. N. Heat capacity and thermal diffusivity of $\mathrm{Cu}_{8} \mathrm{GeSe}_{6}, \mathrm{Cu}_{8} \mathrm{SnS}_{6}$, and $\mathrm{Cu}_{8} \mathrm{GeS}_{6}$. Inorg. Mater. 1989, 25, 1015-1017.

(59) Gulay, L. D.; Parasyuk, O. V.; Romanyuk, Y. E. Preparation and crystal structure of the $\mathrm{Cu}_{9} \mathrm{GeS}_{6-\mathrm{x}}(\mathrm{x}=0.579)$ compound. J. Alloys Compd. 2002, 333, 109-112.

(60) Paar, W. H.; Roberts, A. C.; Berlepsch, P.; Armbruster, T.; Topa, D.; Zagler, G. Putzite, $\left(\mathrm{Cu}_{4.7} \mathrm{Ag}_{3.3}\right)_{\Sigma 8} \mathrm{GeS}_{6}$, a new mineral species from Capillitas, Catamarca, Argentina: description and crystal structure. Can. Mineral. 2004, 42, 1757-1769.

(61) Onoda, M.; Chen, X. A.; Kato, K.; Sato, A.; Wada, H. Structure refinement of $\mathrm{Cu}_{8} \mathrm{GeS}_{6}$ using X-ray diffraction data from a multipletwinned crystal. Acta Cryst. B 1999, 55, 721-725.

(62) Ackermann, J.; Soled, S.; Wold, A.; Kostiner, E. The preparation and characterization of the solid solution series $\mathrm{CuFe}_{\mathrm{x}} \mathrm{Ge}_{1}$. ${ }_{\mathrm{x}} \mathrm{S}_{2}(0.5<\mathrm{x}<1.0)$. J. Solid State Chem. 1976, 19, 75-80.

(63) de Chalbaud, L. M.; Díaz de Delgado, G.; Delgado, J. M.; Mora, A. E.; Sagredo, V. Synthesis and single-crystal structural study of $\mathrm{Cu}_{2} \mathrm{GeS}_{3}$. Mat. Res. Bull. 1997, 32, 1371-1376.

(64) Chen, X.; Onoda, M.; Wada, H.; Sato, A.; Nozaki, H.; HerbstIrmer, R. Preparation, electrical properties, crystal structure, and electronic structures of $\mathrm{Cu}_{4} \mathrm{GeS}_{4}$. J. Solid State Chem. 1999, 145, 204211.

(65) Vaqueiro, P.; Guélou, G.; Kaltzoglou, A.; Smith, R. I.; Barbier, T.; Guilmeau, E.; Powell, A. V. The influence of mobile copper ions on the glass-like thermal conductivity of copper-rich tetrahedrites. Chem. Mater. 2017, 29, 4080-4090. 
Page 11 of 11

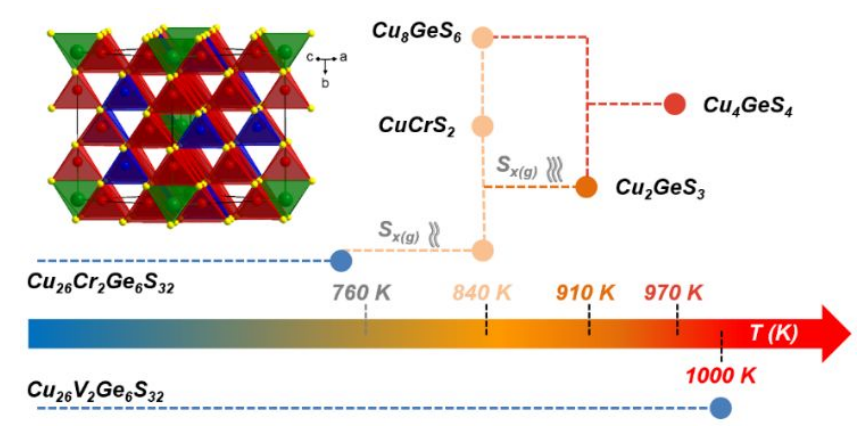

